ARTICLE

https://doi.org/10.1038/s41467-019-11432-1

\title{
Tailoring the photoelectrochemistry of catalytic metal-insulator-semiconductor (MIS) photoanodes by a dissolution method
}

\author{
G. Loget (10 ${ }^{1}$, C. Mériadec ${ }^{2}$, V. Dorcet ${ }^{1}$, B. Fabre (10 ${ }^{1}$, A. Vacher ${ }^{1}$, S. Fryars ${ }^{1} \&$ S. Ababou-Girard ${ }^{2}$
}

Apart from being key structures of modern microelectronics, metal-insulator-semiconductor (MIS) junctions are highly promising electrodes for artificial leaves, i.e. photoelectrochemical cells that can convert sunlight into energy-rich fuels. Here, we demonstrate that homogeneous $\mathrm{Si} / \mathrm{SiO}_{\mathrm{x}} / \mathrm{Ni}$ MIS junctions, employed as photoanodes, can be functionalized with a redox-active species and simultaneously converted into high-photovoltage inhomogeneous MIS junctions by electrochemical dissolution. We also report on the considerable enhancement of performance towards urea oxidation, induced by this process. Finally, we demonstrate that both phenomena can be employed synergistically to design highly-efficient Sibased photoanodes. These findings open doors for the manufacturing of artificial leaves that can generate $\mathrm{H}_{2}$ under solar illumination using contaminated water.

\footnotetext{
${ }^{1}$ Univ Rennes, CNRS, ISCR (Institut des Sciences Chimiques de Rennes)-UMR6226-ScanMAT-UMS2001, F-35000 Rennes, France. ${ }^{2}$ Univ Rennes, CNRS, IPR (Institut de Physique de Rennes)-UMR 6251, F-35000 Rennes, France. Correspondence and requests for materials should be addressed to G.L. (email: gabriel.loget@univ-rennes1.fr)
} 
$\mathrm{S}$ unlight can be directly converted into $\mathrm{H}_{2}$ by photoelectrochemical cells (PECs, a.k.a. artificial leaves), devices that are based on semiconductor (SC) photoelectrodes, immersed in water, that mimic photosynthesis by converting sun's photons into energy-rich molecules ${ }^{1-3}$. The operating principle of PECs relies on the photogeneration of electron-hole pairs $\left(e^{-}-h^{+}\right)$in the SC under solar illumination, the separation of these charge carriers and their transportation at the solid/liquid interface where they react with water. Photogenerated $e^{-}$are employed for the hydrogen evolution reaction (HER, reaction (1)), producing highly pure $\mathrm{H}_{2}$ that can be stored and employed on demand to generate clean electricity. In order to respect electroneutrality, the photogenerated $h^{+}$must be consumed for a counter-reaction, which is generally the oxygen evolution reaction (OER, reaction (2) $)^{4,5}$. Unfortunately, the OER requires a considerable energy input $\left(E_{\mathrm{O} 2 / \mathrm{H} 2 \mathrm{O}}^{0}=1.23 \mathrm{~V}\right.$ vs reversible hydrogen electrode RHE), which limits the overall efficiency of the PEC and generates a low-value product $\left(\mathrm{O}_{2}\right)$. Based on these considerations, it is straightforward that replacing the OER by an electrochemical reaction more valuable or/and proceeding at a lower energy cost would be highly beneficial to increase the efficiency and the added value of $\mathrm{PECs}^{6}$. A very appealing reaction that can be employed at the photoanode side is the urea oxidation reaction (UOR, reaction (3)), which can be triggered at a lower potential than OER on appropriate electrocatalysts ${ }^{7-9}$. Furthermore, very little has been reported on photoelectrochemical $\mathrm{UOR}^{10}$, which is surprising because this reaction allows degrading urea, the main constituent of urine, one of the most abundant wastes on Earth ${ }^{7,11}$.

$$
\begin{gathered}
\text { HER : } 2 \mathrm{H}_{2} \mathrm{O}(\mathrm{l})+2 \mathrm{e}^{-} \rightarrow \mathrm{H}_{2}(\mathrm{~g})+2 \mathrm{OH}^{-}(\mathrm{aq}) \\
\text { OER }: 2 \mathrm{OH}^{-}(\mathrm{aq})+2 \mathrm{~h}^{+} \rightarrow 1 / 2 \mathrm{O}_{2}(\mathrm{~g})+\mathrm{H}_{2} \mathrm{O}(\mathrm{l}) \\
\mathrm{UOR}:\left(\mathrm{NH}_{2}\right)_{2} \mathrm{CO}(\mathrm{aq})+6 \mathrm{OH}^{-}(\mathrm{aq})+6 \mathrm{~h}^{+} \rightarrow \mathrm{N}_{2}(\mathrm{~g})+5 \mathrm{H}_{2} \mathrm{O}(\mathrm{l})+\mathrm{CO}_{2}(\mathrm{~g})
\end{gathered}
$$

Besides, careful consideration of material aspects is crucial for PEC design. In particular, photoelectrodes must: absorb a large portion of the solar spectrum (i.e. have a short band gap $\left(E_{\mathrm{g}}\right)$ ), have a high charge carrier lifetime and be inexpensive. In addition to fulfilling these criteria, $\mathrm{Si}\left(E_{\mathrm{g}}=1.1 \mathrm{eV}\right)$ is highly abundant (the 2nd element on the earth crust), nontoxic and widely employed by the microelectronics and photovoltaic industries, which makes it a prime candidate to be employed for PEC manufacturing ${ }^{12}$. On the other hand, using $\mathrm{Si}$ as a photoelectrode material is a real challenge because of its poor catalytic activity and its notorious instability in aqueous solution ${ }^{13}$. Two main deleterious mechanisms are known to occur on Si-based photoelectrodes, the first one, very pronounced at the photoanode, is the self-oxidation of $\mathrm{Si}$ into $\mathrm{SiO}_{\mathrm{x}}$, which electrically insulates the SC and inhibits charge transfer at the solid/electrolyte interface. The second deactivation process is the chemical etching of Si which is known to occur spontaneously at high $\mathrm{pH}$. Recent remarkable research works revealed that the efficiency and the stability of Si-based OER photoanodes can be considerably increased by incorporating protective and catalytic coatings, such as $\mathrm{Ni}$ thin films ${ }^{14,15}$. Interestingly, several studies have reported that the operation of $\mathrm{Ni}$-coated Si photoanodes at high $\mathrm{pH}$ could lead to considerable performance improvement ${ }^{14,16}$. This process, usually referred as activation, modifies simultaneously the structure as well as the chemical composition of the interface, making difficult to precisely differentiate the effect of single parameters on photovoltage and catalysis. For instance, several hypotheses can be made to explain the enhancement in photovoltage, including oxidation of the Ni layer ${ }^{17}$, partial equilibration of the $n$-Si with the liquid phase $^{14}$ and increase of inhomogeneity in the Ni thin film ${ }^{16}$. In this frame, $\mathrm{Si}$ photoanodes based on the metal-insulator-SC (MIS) junction, a key structure of modern electronics, are attracting considerable attention, owing to their remarkable photoelectrochemical properties ${ }^{18,19}$. Of particular interest, it has been reported lately that inhomogeneous MIS photoanodes ${ }^{20,21}$, manufactured by bottom-up wet processes (e.g. electrodeposition) on $n$-type $\mathrm{Si}(n$-Si) surfaces can be used to efficiently oxidize water at high $\mathrm{pH}^{22}$.

In this article, we report a fundamentally different top-down approach, based on scalable electrodissolution for converting poorly-active homogeneous $\mathrm{Si} / \mathrm{SiO}_{\mathrm{x}} / \mathrm{Ni}$ to highly active inhomogeneous $\mathrm{Si} / \mathrm{SiO}_{\mathrm{x}} / \mathrm{Ni}$ MIS photoanodes. In addition to allowing precise control over the junction inhomogeneity, this method modifies the surface with a redox-active Ni-Prussian blue derivative $(\mathrm{NiFePB})$ which allows a direct probing of the junction properties. We show that the increased inhomogeneity improves the photovoltage $\left(V_{\mathrm{oc}}\right)$ and we demonstrate that the so-processed layers exhibit a pronounced electrocatalytic activity for UOR, which is rationally elucidated. We finally show how electrodissolution can generate synergistic effects in terms of photovoltage and catalytic activity, which allows, in fine, designing efficient UOR photoanodes only composed of highly abundant materials. These results bring new opportunities for the development of PECs that can produce $\mathrm{H}_{2}$ using urea-contaminated water and solar illumination.

\section{Results}

Preparation and characterization of the surfaces. The homogeneous $\mathrm{Si} / \mathrm{SiO}_{\mathrm{x}} / \mathrm{Ni}$ MIS electrodes used as substrates were prepared, first, by chemically oxidizing Si (100) wafers to create a 1.5-nm-thick $\mathrm{SiO}_{\mathrm{x}}$ tunnel layer (as determined by ellipsometry measurements, see Supplementary Fig. 1). After that, a 25-nmthick $\mathrm{Ni}$ layer was deposited on $\mathrm{SiO}_{\mathrm{x}}$ by $\mathrm{DC}$ magnetron sputtering. The so-prepared $\mathrm{Si} / \mathrm{SiO}_{\mathrm{x}} / \mathrm{Ni} \mathrm{MIS}$ electrodes were then modified with $\mathrm{NiFePB}$ by electrochemically oxidizing the Ni layer in the presence of $\mathrm{Fe}(\mathrm{CN})_{6}{ }^{3-}$ at $\mathrm{pH} 2.5$ (Fig. 1a). Indeed, when an anodic current is imposed, $\mathrm{Ni}^{0}$ is converted in soluble $\mathrm{Ni}^{2+}$, which coordinates with the cyano groups of $\mathrm{Fe}(\mathrm{CN})_{6}{ }^{3-}$ to generate the $\mathrm{NiFePB}$ coating at the solid interface. We employed sequential current cycles comprising an anodic pulse $(1 \mathrm{~s})$ followed by a resting time $(3 \mathrm{~s})$ to replenish the diffusion layer with $\mathrm{Fe}(\mathrm{CN})_{6}{ }^{3-}$ (Supplementary Fig. 2 shows the chronopotentiometry curves). In the following, we refer to the $\mathrm{NiFePB}$ coatings as NiFePB-\#cy, with \#cy being the number of imposed electrochemical cycles. This procedure had a pronounced optical effect on the Ni layer, which was studied by employing transparent fluorine-doped tin oxide (FTO)-coated glass slides as substrates, processed in the same manner as for $\mathrm{Si} / \mathrm{SiO}_{\mathrm{x}}$ surfaces. The transmittance of electrodes modified with 25,75 , and 150 electrochemical cycles is reported in Fig. 1b. These spectra and the corresponding optical photographs (Supplementary Fig. 3) show that the layer transmittance increased with the number of electrochemical cycles, well in line with the consumption of the Ni layer. The transmittance maxima varied from $37 \%$ for a nonprocessed FTO/Ni surface to $75 \%$ for $\mathrm{FTO} / \mathrm{Ni} / \mathrm{NiFePB}-150 c y$ (close to the $78 \%$ obtained for bare FTO), which demonstrates that the method improves light transmission through the Ni film, an important parameter for photoelectrode design.

The presence of $\mathrm{CN}$ bonds on the surface after modification was evidenced by attenuated total reflectance Fourier transform infrared spectroscopy (ATR-FTIR), recorded on $p^{+}-\mathrm{Si} / \mathrm{SiO}_{\mathrm{x}} / \mathrm{Ni} /$ $\mathrm{NiFePB}$ in dry air (Fig. 1c). After modification (pink curve), the main band in the $2200-2050 \mathrm{~cm}^{-1}$ region was observed at $2170 \mathrm{~cm}^{-1}$, in close agreement with the reported values for $\mathrm{CN}$ 
a
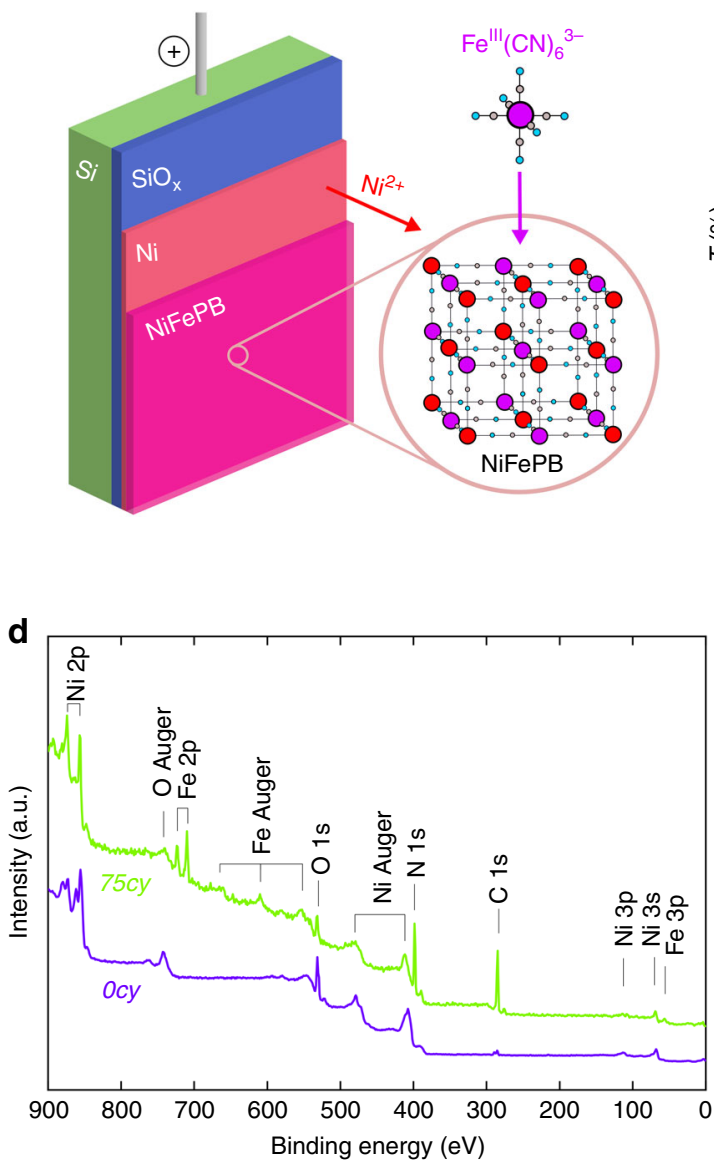

b C
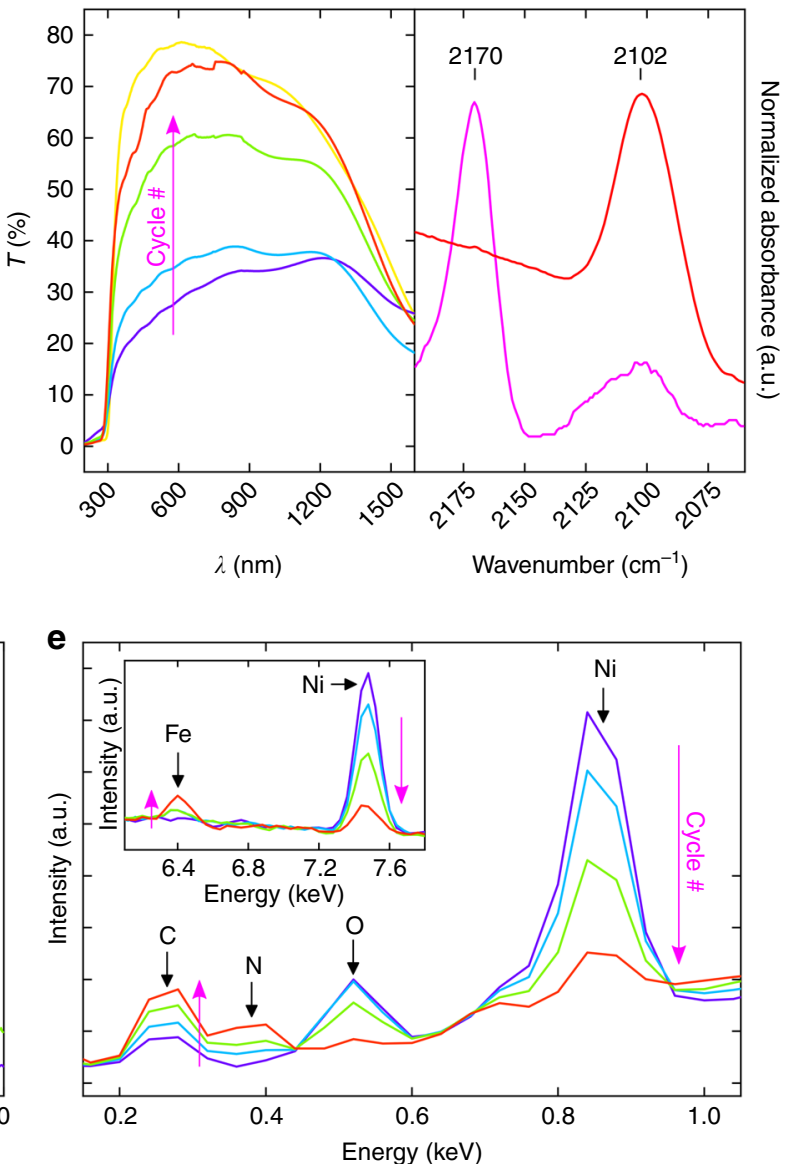

Fig. 1 Physicochemical characterization of the Ni/NiFePB layers. a Scheme showing the method employed for manufacturing the $\mathrm{Si} / \mathrm{SiO} \times \mathrm{Ni} / \mathrm{NiFePB}$ surfaces. b Transmittance spectra of FTO/Ni/NiFePB surfaces obtained with different number of cycles ((purple) 0cy, (light blue) 25cy, (light green) 75cy, (red) $150 c y$, (yellow) bare FTO). c ATR-FTIR spectra of a $p^{+}-\mathrm{Si} / \mathrm{SiO}_{x} / \mathrm{Ni} / \mathrm{NiFePB}$ surface (pink) after preparation and (red) after cathodic polarization in $1 \mathrm{M}$ $\mathrm{KCl}$. d XPS survey spectra recorded for (purple) $p^{+-}-\mathrm{Si} / \mathrm{SiO}_{x} / \mathrm{Ni} / \mathrm{NiFePB}-\mathrm{Ocy}$ and (light green) $p^{+}-\mathrm{Si} / \mathrm{SiO} \times \mathrm{Ni} / \mathrm{NiFePB}-75 \mathrm{cy}$. e EDS spectra of $p^{+-} \mathrm{Si} / \mathrm{SiO}{ }_{x} /$ $\mathrm{Ni} / \mathrm{NiFePB}$ obtained with different number of cycles (purple) Ocy, (light blue) 25cy, (light green) 75cy, and (red) 150cy)

bridging ligands in Prussian blue ${ }^{23}, \mathrm{KNi}^{\mathrm{II}} \mathrm{Fe}^{\mathrm{III}}(\mathrm{CN})_{6}$ and $\mathrm{NiFePB}^{24}$. A smaller band was also observed at $2105 \mathrm{~cm}^{-1}$, which is close to the value reported for $\mathrm{K}_{2} \mathrm{Ni}^{\mathrm{II}} \mathrm{Fe}^{\mathrm{II}}(\mathrm{CN})_{6}{ }^{24}$ and likely indicates the presence of a small amount of $\mathrm{Fe}^{\mathrm{II}}$ in the coating after preparation. Remarkably, after cathodic polarization at $+0.2 \mathrm{~V}$ vs KCl-saturated calomel electrode (SCE) for $30 \mathrm{~s}$ (Fig. 1c, red curve), only one band was observed at $2102 \mathrm{~cm}^{-1}$, confirming the full electrochemical conversion of $\mathrm{Fe}^{\mathrm{III}}$ to $\mathrm{Fe}^{\mathrm{II}}$ in the NiFePB coating. The composition of the outermost electrode surface was analyzed by X-ray photoelectron spectroscopy (XPS, Fig. 1d) before modification $\left(p^{+}-\mathrm{Si} / \mathrm{SiO}_{\mathrm{x}} / \mathrm{Ni} / \mathrm{NiFePB}-0 c y\right.$, violet curve) and after modification $\left(p^{+}-\mathrm{Si} / \mathrm{SiO}_{\mathrm{x}} / \mathrm{Ni} / \mathrm{NiFePB}-75 c y\right.$, green curve). The survey spectra confirmed the presence of all expected elements, i.e., $\mathrm{Ni}$ and $\mathrm{O}$ for the unmodified surface and $\mathrm{Ni}, \mathrm{O}, \mathrm{Fe}$, $\mathrm{N}$, and $\mathrm{C}$ for the modified surface. The presence of oxygen is attributed to the native $\mathrm{NiO} / \mathrm{Ni}(\mathrm{OH})_{2}$ layer that spontaneously forms over $\mathrm{Ni}$ at ambient conditions ${ }^{25}$, which was confirmed by further XPS experiments, described in the SI (Supplementary Fig. 4 and Supplementary Note 1). After modification, the Ni $2 p$ region (Supplementary Fig. 5) exhibited a main peak at $856.3 \mathrm{eV}$, in good agreement with the $\mathrm{Ni} 2 \mathrm{p}_{3 / 2}$ value expected for a $\mathrm{NiFePB}$ layer ${ }^{26}$. In addition, analysis of the $\mathrm{Fe} 2 \mathrm{p}$ region (Supplementary Fig. 6) confirmed the presence of a major Fe ${ }^{\mathrm{III}}$ component and a minor $\mathrm{Fe}^{\mathrm{II}}$ component in the $\mathrm{NiFePB}$ after preparation, with $2 \mathrm{p}_{3 / 2}$ binding energies respectively located at 709.8 and $708.4 \mathrm{eV}$. Furthermore, energy-dispersive X-ray spectroscopy (EDS) allowed investigating the bulk composition of the thin film as a function of the number of electrochemical modification cycles (Fig. 1e, Supplementary Figs. 7 and 8). As shown in this data, the $\mathrm{C}, \mathrm{N}$, and Fe contents increased with the number of cycles; confirming the modification of the $\mathrm{Ni}$ surface with the $\mathrm{NiFePB}$ layer.

The morphological characterization was performed by electron microscopy. A careful analysis of the scanning electron microscopy (SEM) top-view images (Supplementary Figs. 9-12) obtained for $0 c y, 25 c y, 75 c y$, and $150 c y$ allowed elucidating the structure of the coating, which was composed of a NiFePB layer covering the Ni thin film. The NiFePB layer was clearly observed but was, however, ruptured by cracks, likely caused by the surface drying, which allowed observing the morphology of the underlying $\mathrm{Ni}$ thin film. Raising the number of cycles increased the porosity of the Ni film (Supplementary Fig. 11) that ultimately fractured for high cycle number, as demonstrated by the observation of the bare flat $\mathrm{Si} / \mathrm{SiO}_{\mathrm{x}}$ for $\mathrm{Si} / \mathrm{SiO} \mathrm{x}_{\mathrm{x}} / \mathrm{Ni} / \mathrm{NiFePB}-150$ cy (Supplementary Figs. 10d and 11d). Finally, transmission electron microscopy (TEM) was also performed on a thinned $p^{+}-\mathrm{Si} / \mathrm{SiO}_{\mathrm{x}} /$ $\mathrm{Ni} / \mathrm{NiFePB}-75 c y$ to visualize the junction. Figure 2a, and STEMEDS analyses (Supplementary Fig. 13), confirmed the presence of 

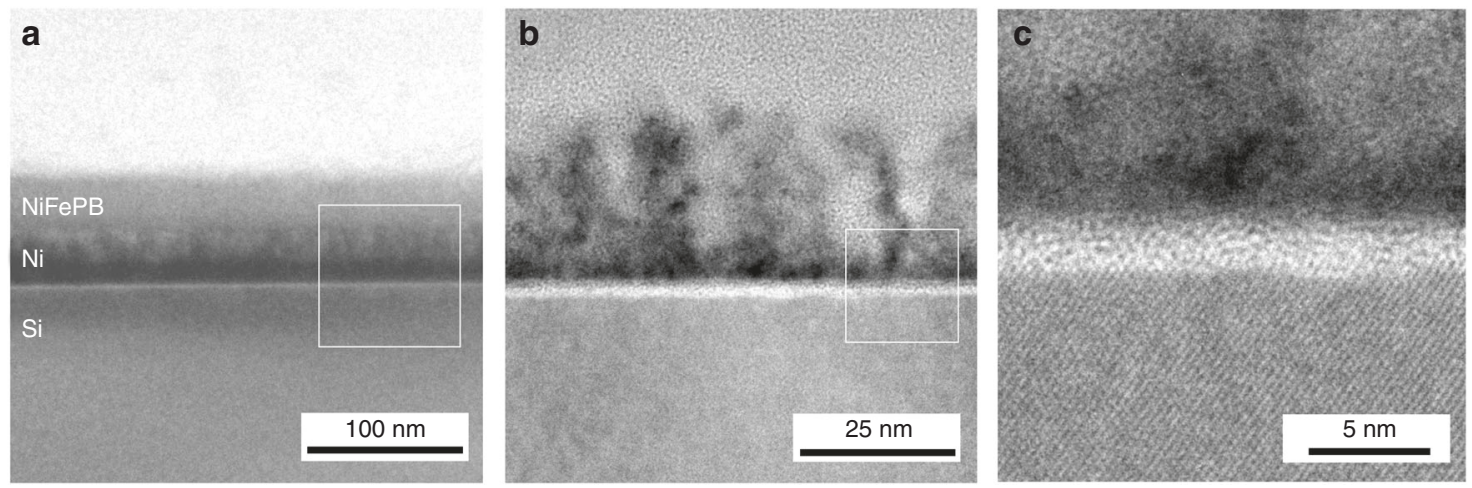

Fig. 2 Characterization of the $\mathrm{Si} / \mathrm{SiO}_{x} / \mathrm{Ni} / \mathrm{NiFePB}$ interface. Cross-sectional TEM images of $p^{+}-\mathrm{Si} / \mathrm{SiO} \times \mathrm{Ni} / \mathrm{NiFePB}-75 c y$. The white square in a indicates the interface that is imaged in $\mathbf{b}$ and the white square in $\mathbf{b}$ indicates the interface that is imaged in $\mathbf{c}$

the NiFePB layer $(\sim 35 \mathrm{~nm})$ over the Ni thin film. High-resolution TEM (Fig. 2b) revealed the amorphous nature of the NiFePB, as well as the high $\mathrm{Ni}$ porosity, generated by the electrodissolution. It is also interesting to note that $\mathrm{NiFePB}$ interpenetrated the $\mathrm{Ni}$ layer, forming a robust interface. The $\mathrm{SiO}_{\mathrm{x}}$ tunnel layer could also be observed between $\mathrm{Si}$ and $\mathrm{Ni}$ (Fig. 2c), and had a thickness of $1.9 \mathrm{~nm}$, in close agreement with the ellipsometric value (Supplementary Fig. 1). To sum up, the combination of the characterization data demonstrates the conversion of the initially homogeneous $\mathrm{Si} / \mathrm{SiO}_{x} / \mathrm{Ni}$ to a highly inhomogeneous $\mathrm{Si} / \mathrm{SiO}_{\mathrm{x}} / \mathrm{Ni}$ / $\mathrm{NiFePB}$ MIS junction. This structure, where the redox-active layer $(\mathrm{NiFePB})$ is immobilized on the $\mathrm{Ni}$ thin film, should allow to directly probe the photoelectrochemistry of the junction in a much less harsher environment than the typical strongly alkaline solutions employed for OER or UOR, precluding $\mathrm{Ni}$ oxidation and enabling a precise evaluation of the effect of inhomogeneity on photovoltage.

Electrochemistry and photoelectrochemistry in $1 \mathrm{M} \mathrm{KCl}$. The electrochemical activity of the $p^{+}-\mathrm{Si}$ MIS anodes, recorded in the dark in $1 \mathrm{M} \mathrm{KCl}$ is first presented in Fig. 3a. Unlike the homogeneous $p^{+}-\mathrm{Si} / \mathrm{SiO}_{\mathrm{x}} / \mathrm{Ni}$ anode (purple curve), the $p^{+}-\mathrm{Si} / \mathrm{SiO}_{\mathrm{x}} / \mathrm{Ni} /$ $\mathrm{NiFePB}$ anodes exhibited a marked redox activity, as shown by the reversible wave that was observed for all modified electrodes. This wave corresponds to the $\mathrm{Fe}^{\mathrm{III}} / \mathrm{Fe}^{\mathrm{II}}$ redox couple in $\mathrm{NiFePB}$, as supported by (i) the value of the apparent standard potential $\left(E^{0^{\prime}}=\right.$ $0.47 \mathrm{~V}$ vs SCE, Supplementary Table 1 ), which is very close to that reported in the literature for similar Prussian blue systems ${ }^{24}$ as well as (ii) the linear relationship between the current density of the redox peaks and the scan rate (Supplementary Fig. 14) that demonstrates the immobilized nature of the redox system ${ }^{27}$. As it can be observed in Fig. $3 \mathrm{~b}$, the $\mathrm{Fe}^{\mathrm{III}} / \mathrm{Fe}^{\mathrm{II}}$ redox system was also observed for $n-\mathrm{Si} / \mathrm{SiO}_{\mathrm{x}} / \mathrm{Ni} / \mathrm{NiFePB}$ photoanodes under illumination with simulated sunlight, though, at a lower $E^{0^{\prime}}$ value, which was dependent on the cycle number. In the dark, the redox waves were also observed (Supplementary Fig. 15) but at a $E^{0^{\prime}}$ that was constant for all $n-\mathrm{Si} / \mathrm{SiO}_{\mathrm{x}} / \mathrm{Ni} / \mathrm{NiFePB}\left(E^{0^{\prime}}=0.46 \mathrm{~V}\right.$ vs SCE, Supplementary Table 1) and statistically identical to that recorded on $p^{+}-\mathrm{Si} / \mathrm{SiO}_{\mathrm{x}} /$ $\mathrm{Ni} / \mathrm{NiFePB}$ anodes. Figure $3 \mathrm{c}$ illustrates this phenomenon for $\mathrm{Si} /$ $\mathrm{SiO}_{\mathrm{x}} / \mathrm{Ni} / \mathrm{NiFePB}-75 c y$, which suggests that the dark oxidation of the $\mathrm{NiFePB}$ coating is achieved through $e^{-}$injection into the Si conduction band, as opposed to the oxidation under illumination, which occurs through the injection of photogenerated $h^{+}$from the Si valence band to the NiFePB (Supplementary Fig. 16). It can be clearly observed in Fig. $3 \mathrm{~b}$ that the $E^{0^{\prime}}$ value decreased with an increasing number of cycles, implying a considerable improvement of the photovoltage $\left(V_{\mathrm{oc}}\right)$. Note that the unconventional $\mathrm{CV}$ shape obtained for $n$-Si/SiO $/ \mathrm{Ni} / \mathrm{NiFePB}-150 c y$ under illumination, characterized by an inverted position of the oxidation and the reduction waves (the reduction wave occurs at a more positive potential than the oxidation wave), was reproducible and is attributed to the electrostatic interactions between the $\mathrm{NiFePB}$ layer and the charges in the space-charge layer ${ }^{28}$.

The anodic charge $(Q)$ corresponding to the oxidation of $\mathrm{Fe}^{\mathrm{II}}$ into $\mathrm{Fe}^{\mathrm{III}}$ was extracted from the $\mathrm{CV}$ s and studied as a function of the number of cycles. While $Q$ was found independent on the $\mathrm{Si}$ doping, a remarkable dependency with the cycle number was found (Fig. 3d). Indeed, $Q$ increased linearly (due to the increase of the $\mathrm{NiFePB}$ layer thickness), up to a maximum value of $1.1 \mathrm{mC} \mathrm{cm}^{-2}$ at $75 c y$ (corresponding to a $1.1 \times 10^{-8} \mathrm{~mol} \mathrm{~cm}^{-2}$ surface coverage in electroactive Fe centers), and decayed for a higher number of cycles. The decrease can be explained by the fracturing of the Ni thin film (that was evidenced for high cycle numbers by SEM, Supplementary Figs. 10d and 11d), which disrupts the charge conduction pathway between $\mathrm{NiFePB}$ and $\mathrm{Si}$, thus lowering the number of electrochemically addressable Fe centers. The photovoltage $\left(V_{\mathrm{oc}}\right)$ generated at the $n-\mathrm{Si} / \mathrm{SiO}_{\mathrm{x}} / \mathrm{Ni} / \mathrm{NiFePB}$ surfaces was determined either from the open-circuit potentials (OCPs, Supplementary Fig. 17) or the $E^{0^{\prime}}$ values extracted from the CVs, both in the dark and under illumination in $1 \mathrm{M} \mathrm{KCl}$, as shown in Fig. 3e. The resulting $V_{\mathrm{oc}}$ values are plotted in Fig. $3 \mathrm{f}$ as a function of the number of cycles. From this curve, it is clear that the modification improved $V_{o c}$, that varied from $0.18 \mathrm{~V}$ for the unmodified, homogeneous $n-\mathrm{Si} / \mathrm{SiO}_{\mathrm{x}} / \mathrm{Ni}$ MIS electrode to $0.40 \mathrm{~V}$ for $n-\mathrm{Si} / \mathrm{SiO}_{\mathrm{x}} / \mathrm{Ni} / \mathrm{NiFePB}-150 c y$. Additional OCP measurements were performed in electrolytes containing the dissolved $\mathrm{Fe}(\mathrm{CN})_{6}{ }^{3-}$ and $\mathrm{Fe}(\mathrm{CN})_{6}{ }^{4-}$ redox species at concentration ratios ranging from $10^{-3}$ to $10^{3}$ (Supplementary Fig. 18a, b). The resulting $V_{\text {oc }}$ values were comprised between 0.27 to $0.32 \mathrm{~V}$, a difference which is about seven times smaller than the $360 \mathrm{mV}$-shift of solution potential predicted by the Nernst equation. In addition, OCP measurements in equimolar solutions of the $\mathrm{Fe}(\mathrm{CN})_{6}{ }^{3-} / \mathrm{Fe}$ $(\mathrm{CN})_{6}{ }^{4-}$ and $\mathrm{Ru}\left(\mathrm{NH}_{3}\right)^{3+} / \mathrm{Ru}\left(\mathrm{NH}_{3}\right)^{2+}$ redox couples (Supplementary Fig. 18c) as well as measurements in an electrolyte saturated with $\mathrm{Ar}$ and $\mathrm{O}_{2}$ gases (Supplementary Fig. 18d), indicated, in all cases, $V_{\text {oc }}$ values comprised between 0.29 and $0.32 \mathrm{~V}$. These OCP measurements demonstrate that $V_{\mathrm{oc}}$ is independent of the solution potential and that the photovoltage is controlled by the solid interface. Based on this series of photoelectrochemical experiments and on the previously discussed characterization data, the increase of $V_{\mathrm{oc}}$ with the cycle number can be rationally explained by the dissolution of the Ni layer, which induces the formation of pores in the Ni metal thin film (Supplementary Figs. 10 and 11). The layer permeation disrupts the initially continuous $\mathrm{Si} / \mathrm{SiO}_{\mathrm{x}} / \mathrm{Ni}$ tunnel Schottky junction and generates Ni-deficient $\mathrm{Si} / \mathrm{SiO}_{\mathrm{x}}$ regions with a 

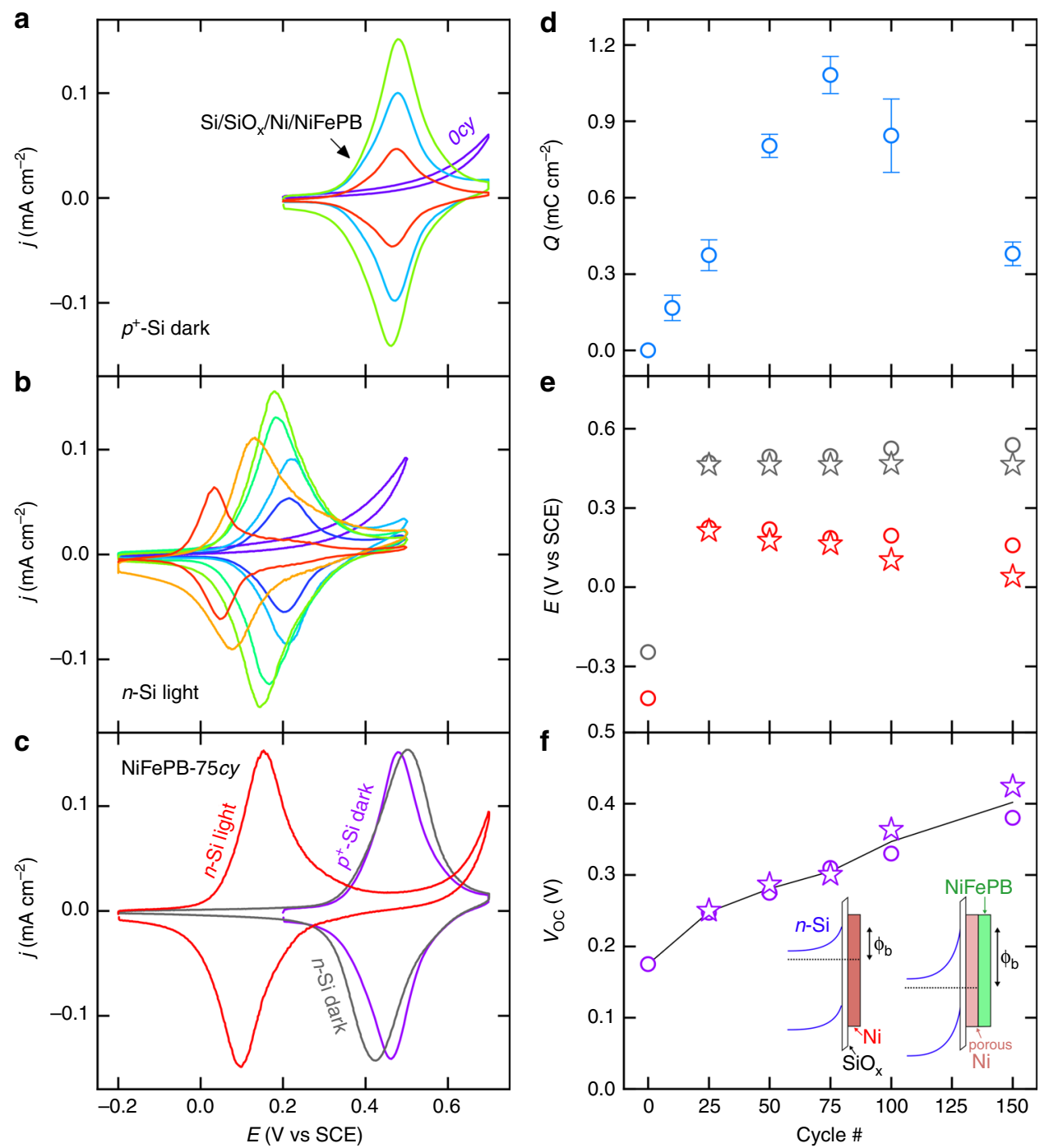

Fig. 3 Electrochemistry and photoelectrochemistry of $\mathrm{Si} / \mathrm{SiO}_{x} / \mathrm{Ni} / \mathrm{NiFePB}$ anodes. $\mathbf{a}, \mathbf{b} \mathrm{CVs}$ recorded $\mathbf{a}$ in the dark on $p^{+}-\mathrm{Si} / \mathrm{SiO}{ }_{x} / \mathrm{Ni} / \mathrm{NiFePB}$ and $\mathbf{b}$ under simulated sunlight on $n-\mathrm{Si} / \mathrm{SiO}_{x} / \mathrm{Ni} / \mathrm{NiFePB}$, prepared with different number of cycles ((purple) 0cy, (dark blue) 10cy, (light blue) 25cy, (cyan) 50cy, (light green) 75cy, (yellow) 100cy, and (red) $150 \mathrm{cy}$ ). c CVs recorded in the dark on (purple) $p^{+-}-\mathrm{Si} / \mathrm{SiO}_{x} / \mathrm{Ni} / \mathrm{NiFePB}-75 c y$ and $(\mathrm{gray}) n-\mathrm{Si} / \mathrm{SiO} \times \mathrm{Ni} / \mathrm{NiFePB}-75 \mathrm{cy}$ and under simulated sunlight on (red) $n-\mathrm{Si} / \mathrm{SiO}_{x} / \mathrm{Ni} / \mathrm{NiFePB}-75 c y$. d Integrated average charge of the oxidation peak for $\mathrm{Si} / \mathrm{SiO} \times / \mathrm{Ni} / \mathrm{NiFePB}$ anodes as a function of the number of cycles (the errors bars represent the standard deviation of at least four independent measurements). e $V a$ alues of (disks) OCP and (stars) $E^{O^{\prime}}$ measured in the dark (gray) and under simulated sunlight (red) on $n$ - $\mathrm{Si} / \mathrm{SiO}_{x} / \mathrm{Ni} / \mathrm{NiFePB}$ as a function of the number of cycles. $\mathbf{f} \mathrm{Values}$ of $V_{\text {oc }}$ determined by (purple disks) OCP and (purple stars) $E^{\mathrm{O}^{\prime}}$ measurements on $n-\mathrm{Si} / \mathrm{SiO}_{x} / \mathrm{Ni} / \mathrm{NiFePB}$ as a function of the number of cycles. The black curve represents the variation of the average value. Inset: schematic band diagrams of left) $n-\mathrm{Si} / \mathrm{SiO}_{x} / \mathrm{Ni}$ and right) $n-\mathrm{Si} / \mathrm{SiO} \times \mathrm{Ni} / \mathrm{NiFePB}$ junctions in the dark, showing the increasing of the barrier height $\left(\phi_{\mathrm{b}}\right)$ after modification. All measurements were performed in $\mathrm{Ar}$-saturated $1 \mathrm{M} \mathrm{KCl}$, the $\mathrm{CVs}$ were recorded at $10 \mathrm{mVs}^{-1}$

larger barrier height $\left(\phi_{\mathrm{b}}\right)$, thus improving the photoanode overall $V_{\mathrm{oc}}$ (Fig. 3f, inset). Such a behavior has been previously observed $^{20,22,29}$ and discussed in the context of OER photoanodes ${ }^{16}$ as well as solid-liquid solar cells ${ }^{30}$ and the high $\phi_{\mathrm{b}}$ in these $\mathrm{Si} / \mathrm{SiO}_{\mathrm{x}}$ regions is thought to originate from the unpinning of the Schottky junction or from the equilibration of the Si with defect states in the $\mathrm{SiO}_{\mathrm{x}}$. To summarize, the photoelectrochemical experiments demonstrate that the electrodissolution method considerably improved the photovoltage of homogeneous $n$-Si/SiO $/ \mathrm{Ni}$ MIS electrodes by disrupting the Schottky junction. Now, we discuss their catalytic activity.

Electrochemistry in $\mathbf{1 ~ M ~ K O H . ~ I n ~ o r d e r ~ t o ~ o n l y ~ a s s e s s ~ t h e ~}$ electrocatalytic activity of the $\mathrm{Ni} / \mathrm{NiFePB}$ layers and to preclude light-induced phenomena, we studied the anodic behavior of the $p^{+}-\mathrm{Si} / \mathrm{SiO}_{\mathrm{x}} / \mathrm{Ni} / \mathrm{NiFePB} \mathrm{MIS}$ anodes in the dark in $1 \mathrm{M} \mathrm{KOH}$, with a particular focus on UOR. As illustrated by Fig. 4a, which shows the anodic behavior for $p^{+}-\mathrm{Si} / \mathrm{SiO}_{\mathrm{x}} / \mathrm{Ni} / \mathrm{NiFePB}-75 c y$, the anodes exhibited distinct electrochemical responses in the presence and in the absence of urea. It is also interesting to note the absence of electrochemical response of $p^{+}-\mathrm{Si} / \mathrm{SiO}_{\mathrm{x}}$ in both media (black voltammograms of Fig. $4 \mathrm{a}, \mathrm{b}$ ) revealing the absolute necessity of using the Ni coating for promoting charge transfer. In the case of the $p^{+}-\mathrm{Si} / \mathrm{SiO}_{\mathrm{x}} / \mathrm{Ni} / \mathrm{NiFePB}$ electrodes, a quasi-reversible redox wave was observed in the absence of urea at $\sim 1.37 \mathrm{~V}$ vs RHE (Supplementary Fig. 19a), attributed to the $\mathrm{Ni}{ }^{\mathrm{III}} / \mathrm{Ni}^{\mathrm{II}}$ system (generally observed for the $\mathrm{NiOOH} / \mathrm{Ni}(\mathrm{OH})_{2}$ redox couple in alkaline solutions) ${ }^{31}$, followed by OER at potentials $>1.5 \mathrm{~V}$ vs 

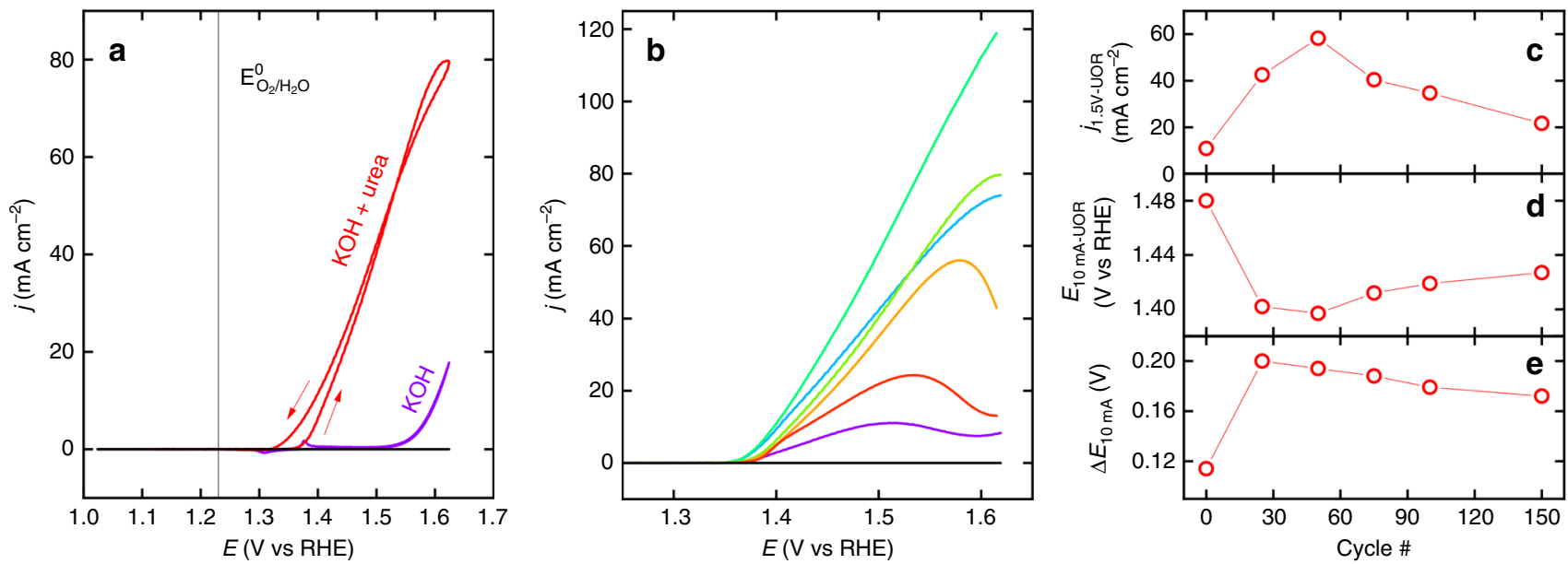

Fig. 4 Electrocatalytic activity of $p^{+-}-\mathrm{Si} / \mathrm{SiO}_{x} / \mathrm{Ni} / \mathrm{NiFePB}$ anodes. a $\mathrm{CVs}$ of (black) $p^{+-}-\mathrm{Si} / \mathrm{SiO}_{x}$ in $1 \mathrm{M} \mathrm{KOH}$, (purple) $p^{+-}-\mathrm{Si} / \mathrm{SiO} \times \mathrm{Ni} / \mathrm{NiFePB}-75 c y$ in $1 \mathrm{M} \mathrm{KOH}$ and in (red) $p^{+-} \mathrm{Si} / \mathrm{SiO}_{x} / \mathrm{Ni} / \mathrm{NiFePB}-75 c y$ in $1 \mathrm{M} \mathrm{KOH}+0.33 \mathrm{M}$ urea, the arrows indicate the sweep direction. b $\mathrm{LSVs}_{\mathrm{S}}$ of (black) $p^{+-}-\mathrm{Si} / \mathrm{SiO}$ and $p^{+-} \mathrm{Si} / \mathrm{SiO} \mathrm{O}_{x} /$ $\mathrm{Ni} / \mathrm{NiFePB}$, prepared with different number of cycles ((purple) 0cy, (light blue) 25cy, (cyan) 50cy, (light green) 75cy, (yellow) 100cy, (red) 150cy) in 1 M

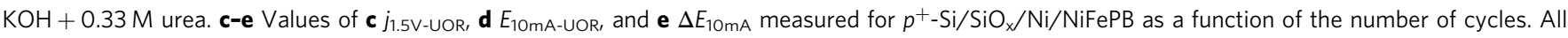
voltammograms were recorded at $10 \mathrm{mV} \mathrm{s}^{-1}$ in the dark

RHE (Supplementary Fig. 19b). In the presence of $0.33 \mathrm{M}$ of urea (this concentration was used because it is the average concentration in human urine $\mathrm{e}^{7}$ and also a benchmark in the UORrelated literature, Supplementary Table 2) a catalytic current appeared at the position of the $\mathrm{Ni}{ }^{\mathrm{III}} / \mathrm{Ni}^{\mathrm{II}}$ oxidation wave, attributed to UOR, in good agreement with the literature ${ }^{7-9}$.

Figure $4 \mathrm{~b}$ compares linear sweep voltammograms (LSVs) recorded on $\mathrm{Si} / \mathrm{SiO}_{\mathrm{x}}$ and $\mathrm{Si} / \mathrm{SiO}_{\mathrm{x}} / \mathrm{Ni} / \mathrm{NiFePB}$ prepared with electrochemical cycles ranging from $0 c y$ to $150 c y$, in the ureacontaining electrolyte (CVs are presented in Supplementary Fig. 20). UOR was observed for all MIS anodes with a catalytic activity that was clearly dependent on the number of cycles. Figure $4 \mathrm{c}-\mathrm{e}$ show respectively the benchmark values of current density at $1.5 \mathrm{~V}$ vs RHE ( $\left.j_{1.5 \mathrm{~V} \text {-UOR }}\right)$, potential at $j=10 \mathrm{~mA} \mathrm{~cm}^{-2}$ $\left(E_{10 \mathrm{~mA}}\right)$ in the presence of urea $\left(E_{10 \mathrm{~mA}-\mathrm{UOR}}\right)$, as well as the difference between the $E_{10 \mathrm{~mA}}$ values measured in the absence and in the presence of urea $\left(\Delta E_{10 \mathrm{~mA}}=E_{10 \mathrm{~mA}-\mathrm{OER}}-E_{10 \mathrm{~mA}-\mathrm{UOR}}\right)$. In other words, $\Delta E_{10 \mathrm{~mA}}$ represents the gain of potential brought by UOR as a function of the number of cycles; while the lowest $\Delta E_{10 \mathrm{~mA}}(0.11 \mathrm{~V})$ was obtained for the homogeneous $p^{+}-\mathrm{Si} / \mathrm{SiO}_{\mathrm{x}} / \mathrm{Ni}$, the modified $p^{+}-\mathrm{Si} / \mathrm{SiO}_{\mathrm{x}} / \mathrm{Ni} / \mathrm{NiFePB}$ surfaces presented a $\Delta E_{10 \mathrm{~mA}}$ comprised between 0.17 and $0.20 \mathrm{~V}$ (Fig. $4 \mathrm{e}$ ). $E_{10 \mathrm{~mA} \text {-UOR }}$ represents the thermodynamic requirement to reach a benchmark catalytic $j$ of $10 \mathrm{~mA} \mathrm{~cm}^{-2}$ and it can be observed that $E_{10 \mathrm{~mA}-U O R}$ was maximum for $p^{+}-\mathrm{Si} / \mathrm{SiO}_{\mathrm{x}} / \mathrm{Ni}(1.48 \mathrm{~V}$ vs RHE) and significantly lower for the $p^{+}-\mathrm{Si}_{\mathrm{SiO}} / \mathrm{Ni} / \mathrm{NiFePB}$ anodes (Fig. $4 \mathrm{~d}$ ), with a minimum value of $1.40 \mathrm{~V}$ vs $\mathrm{RHE}$ for $p^{+}-\mathrm{Si} / \mathrm{SiO}_{\mathrm{x}} / \mathrm{Ni} /$ $\mathrm{NiFePB}-50 c y$. Interestingly, this anode also exhibited the highest

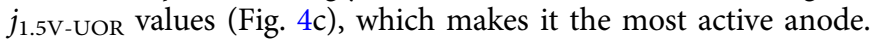
Conversely, all benchmark values recorded for the homogeneous $p^{+}-\mathrm{Si} / \mathrm{SiO}_{\mathrm{x}} / \mathrm{Ni}$ were the worst among all tested MIS anodes, making it the least active anode. These results show that the electrochemical dissolution method improves considerably UOR; next, we investigate the origin of this behavior.

Characterization of the active phase. In order to gain insights into both chemical and structural compositions of the UORactive phase, $p^{+}-\mathrm{Si} / \mathrm{SiO}_{\mathrm{x}} / \mathrm{Ni} / \mathrm{NiFePB}-75 c y$ surfaces were characterized before and after UOR by a series of analytical techniques, which all unveiled a drastic change of the surface under UOR conditions. First, CVs in $1 \mathrm{M} \mathrm{KCl}$ (Fig. 5a) showed the total inhibition of the $\mathrm{Fe}^{\mathrm{III}} / \mathrm{Fe}^{\mathrm{II}}$ redox wave (vide supra) after UOR. Second, XPS revealed a clear chemical evolution of the outermost interface. This appeared as a change in the composition of the $\mathrm{Ni}$ phase, indicated by an increase of the intensity of the Ni $2 p$ peaks as well as a $-0.6 \mathrm{eV}$-shift of the $\mathrm{Ni} 2 \mathrm{p}_{3 / 2}$ binding energy (Fig. 5e). In addition, XPS unveiled a total loss of the Fe (Fig. $5 \mathrm{f}$ ) and $\mathrm{N}$ (Fig. $5 \mathrm{~g}$ ) contents (if $\mathrm{Fe}$ atoms are present in this layer, Fig. $5 \mathrm{f}$ indicates that their amount is below the XPS detection limit). These results are consistent with the decomposition of $\mathrm{NiFePB}$ into $\mathrm{Ni}(\mathrm{OH})_{2}$ and $\mathrm{Fe}$ hydroxides, the latter being simultaneously released in solution, a behavior that has been previously reported for Prussian blue derivatives immersed in highly alkaline media ${ }^{24}$. This is well in line with the $\mathrm{Ni} 2 \mathrm{p}$ spectrum obtained after UOR, which is strictly identical to that reported for $\mathrm{Ni}(\mathrm{OH})_{2}{ }^{32}$. Furthermore, SEM revealed considerable structural changes (Fig. 5b, c) and confirmed the removal of the NiFePB film during UOR (additional SEM images are shown in Supplementary Figs. 21 and 22). To sum up, the characterization results obtained after UOR demonstrate that, in these conditions, $\mathrm{NiFePB}$ reacts with $\mathrm{KOH}$ to generate a $\mathrm{Ni}(\mathrm{OH})_{2}$ phase on the $\mathrm{Ni}$ film, which is electrochemically converted to $\mathrm{NiOOH}$ at potentials more positive than $1.37 \mathrm{~V}$ vs RHE (Supplementary Fig. 19a) ${ }^{31,33}$. The considerable improvement in catalytic activity observed between the unmodified homogeneous $\mathrm{Si} / \mathrm{SiO}_{\mathrm{x}} / \mathrm{Ni}$ and the inhomogeneous $\mathrm{Si} / \mathrm{SiO}_{\mathrm{x}} / \mathrm{Ni} / \mathrm{NiFePB} \mathrm{MIS}$ electrodes (Fig. $4 \mathrm{~b}-\mathrm{e}$ ) indicates a relationship between the UOR activity and the porous $\mathrm{Ni}(\mathrm{OH})_{2}$ phase that is converted, during UOR, to a dense area of highly active $\mathrm{NiOOH}$ catalytic sites ${ }^{7-9}$. The evolution of the catalytic activity is thus correlated with the amount of porous $\mathrm{Ni}(\mathrm{OH})_{2}$ on the surface, which, according to the SEM analysis (Supplementary Fig. 11) and the charge under the $\mathrm{Ni} \mathrm{III}^{\mathrm{II}} / \mathrm{Ni}^{\mathrm{II}}$ redox wave (Supplementary Fig. 19a), first increases with the number of cycles and then decreases for prolonged electrodissolution (i.e. for cycle number $>50$ ). Based on these results, clearly showing the conversion of $\mathrm{NiFePB}$ into $\mathrm{Ni}(\mathrm{OH})_{2}$ under the UOR conditions, we will now refer to the $\mathrm{Si} / \mathrm{SiO} / \mathrm{Ni} / \mathrm{NiFePB}$-\#cy surfaces that are used for $\mathrm{UOR}$ as $\mathrm{Si} / \mathrm{SiO}_{\mathrm{x}} / \mathrm{Ni} / \mathrm{Ni}(\mathrm{OH})_{2}$-\#cy.

Photoelectrochemistry in $1 \mathrm{M} \mathrm{KOH}$. Having addressed systematically the two beneficial effects of the electrodissolution method, namely, the improvement of the photovoltage at the MIS Schottky 




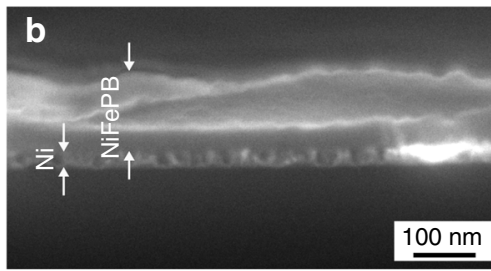

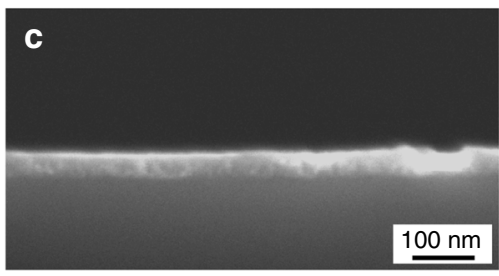

d

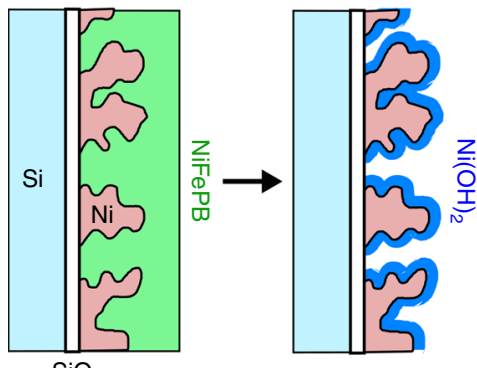

$\mathrm{SiO}_{x}$

e

$\mathbf{f}$

g

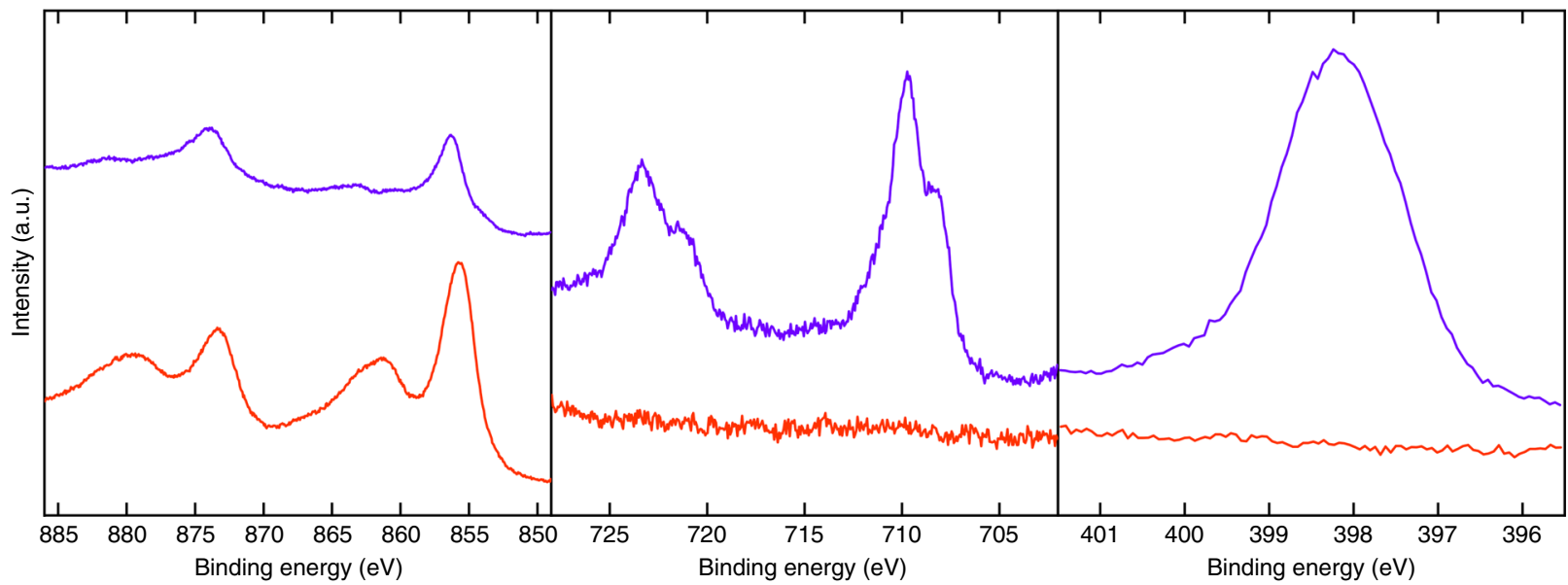

Fig. 5 Characterization of the UOR-active phase. a CVs in $1 \mathrm{M} \mathrm{KCl}$ of $p^{+-} \mathrm{Si} / \mathrm{SiO} \times / \mathrm{Ni} / \mathrm{NiFePB}-75 c y$ at $10 \mathrm{mV} \mathrm{s}^{-1}$ in the dark (purple) after preparation and (red) after UOR. b, $\mathbf{c}$ Cross-section SEM images of $p^{+-} \mathrm{Si} / \mathrm{SiO}_{x} / \mathrm{Ni} / \mathrm{NiFePB}-75 \mathrm{cy} \mathbf{b}$ after preparation and $\mathbf{c}$ after UOR. $\mathbf{d}$ Scheme showing the changes occurring at a $\mathrm{Si} / \mathrm{SiO}_{x} / \mathrm{Ni} / \mathrm{NiFePB}$ surface during UOR. e-g XPS spectra showing e Ni 2p, f Fe 2p, and $\mathbf{g ~ N ~} 1 \mathrm{~s}$ regions; for $p^{+}-\mathrm{Si} / \mathrm{SiO} \times / \mathrm{Ni} / \mathrm{NiFePB}-75 c y$ (purple) after preparation and (red) after UOR

junction (Fig. 3) and the improvement of the UOR electrocatalysis on the metal thin film (Fig. 4), we now combine both effects by employing photoactive $n-\mathrm{Si} / \mathrm{SiO} \mathrm{x}_{\mathrm{x}} / \mathrm{Ni} / \mathrm{Ni}(\mathrm{OH})_{2}$ for UOR. Figure $6 \mathrm{a}$ presents the CVs recorded on $n-\mathrm{Si} / \mathrm{SiO} / \mathrm{Ni} / \mathrm{Ni}(\mathrm{OH})_{2}-75 c y$ in $1 \mathrm{M}$ $\mathrm{KOH}$ in the dark and under illumination, in the absence and in the presence of urea. The current densities obtained in the dark were very small $\left(<1.5 \mathrm{~mA} \mathrm{~cm}^{-2}\right)$, conversely, they became much higher under illumination $\left(j_{\max }=20.6 \mathrm{~mA} \mathrm{~cm}^{-2}\right)$, showing that photogenerated holes triggered OER and UOR at high rates (inset of Fig. 6e). Figure $6 \mathrm{a}$ also demonstrates the gain of electrical energy that occurs for both reactions when employing illuminated $n$-Si instead of non-photoactive $p^{+}-\mathrm{Si}$. The potential gain at the illuminated $n$ $\mathrm{Si} / \mathrm{SiO}_{\mathrm{x}} / \mathrm{Ni} / \mathrm{Ni}(\mathrm{OH})_{2}-75 c y$ was $0.28 \mathrm{~V}$ at $j=10 \mathrm{~mA} \mathrm{~cm}^{-2}$ (for both OER and UOR, Supplementary Fig. 23), in good agreement with the $V_{\text {oc }}$ previously measured on $n-\mathrm{Si} / \mathrm{SiO}_{\mathrm{x}} / \mathrm{Ni} / \mathrm{NiFePB}-75 c y \quad(0.30 \mathrm{~V}$, Fig. 3f). Additional OCP measurements performed in an aqueous electrolyte containing dissolved $\mathrm{Fe}(\mathrm{CN})_{6}{ }^{3-}$ and $\mathrm{Fe}(\mathrm{CN})_{6}{ }^{4-}$ on $n$-Si/SiO $/ \mathrm{Ni} / \mathrm{NiFePB}-75 c y$ before and after UOR (Supplementary Fig. 24) revealed, in both cases a $V_{\mathrm{oc}}$ value of $0.30 \mathrm{~V}$, showing that the removal of the NiFePB layer did not influence $V_{\text {oc }}$. This confirms that the photovoltage is, in any case, controlled by the inhomogeneous $\mathrm{Si} / \mathrm{SiO}_{\mathrm{x}} / \mathrm{Ni}$ junction and that the electrolyte-permeable $\mathrm{NiFePB}$ and $\mathrm{Ni}(\mathrm{OH})_{2}$ layers do not contribute to $V_{\mathrm{oc}}$.
In addition to this gain caused by the illuminated MIS junction, UOR further shifts negatively the voltammograms with respect to OER, by $\Delta E_{10 \mathrm{~mA}}=0.19 \mathrm{~V}$ on $n-\mathrm{Si} / \mathrm{SiO}_{\mathrm{x}} / \mathrm{Ni} / \mathrm{Ni}(\mathrm{OH})_{2}-75 c y$. This value is in perfect agreement with that measured on nonphotoactive $p^{+}-\mathrm{Si} / \mathrm{SiO}_{\mathrm{x}} / \mathrm{Ni} / \mathrm{Ni}(\mathrm{OH})_{2}-75 c y$ (Fig. 4a) confirming that this gain is entirely induced by UOR. The combination of both phenomena allows generating an overall thermodynamic gain of $0.47 \mathrm{~V}$, leading to $E_{10 \mathrm{~mA}}=1.13 \mathrm{~V}$ vs RHE for $n-\mathrm{Si} / \mathrm{SiO}_{\mathrm{x}} /$ $\mathrm{Ni} / \mathrm{Ni}(\mathrm{OH})_{2}-75 c y$ in the presence of urea. Remarkably, note that, in these conditions, the photocurrent plateau is almost reached at the standard potential of the $\mathrm{O}_{2} / \mathrm{H}_{2} \mathrm{O}$ couple, which is something normally only obtained with $\mathrm{Si}$ photoanodes bearing a buried $n p^{+}$ junction $^{34-36}$ clearly demonstrating the importance of electrolyte composition for improving the performance of the electrodes and saving energy for $\mathrm{H}_{2}$ production in PECs. Figure $6 \mathrm{~b}$ shows the LSVs recorded under illumination in the presence of urea on $n-\mathrm{Si} / \mathrm{SiO}_{\mathrm{x}}$ and $n-\mathrm{Si} / \mathrm{SiO} \mathrm{x}_{\mathrm{x}} / \mathrm{Ni} / \mathrm{Ni}(\mathrm{OH})_{2}$ surfaces modified with 0 to 150 cycles (corresponding CVs are shown in Supplementary Fig. 25). The voltammogram shape is quite indicative of the processes occurring at the illuminated photoanode, with a slope reflecting the reaction kinetics. Indeed, as demonstrated for $p^{+}-\mathrm{Si}_{\mathrm{SiO}} / \mathrm{Ni} / \mathrm{Ni}(\mathrm{OH})_{2}$ (Fig. $4 \mathrm{~b}$ ), UOR is much slower on the unmodified surface $\left(n-\mathrm{Si} / \mathrm{SiO}_{\mathrm{x}} / \mathrm{Ni} / \mathrm{Ni}(\mathrm{OH})_{2}-0 c y\right)$ with respect to 

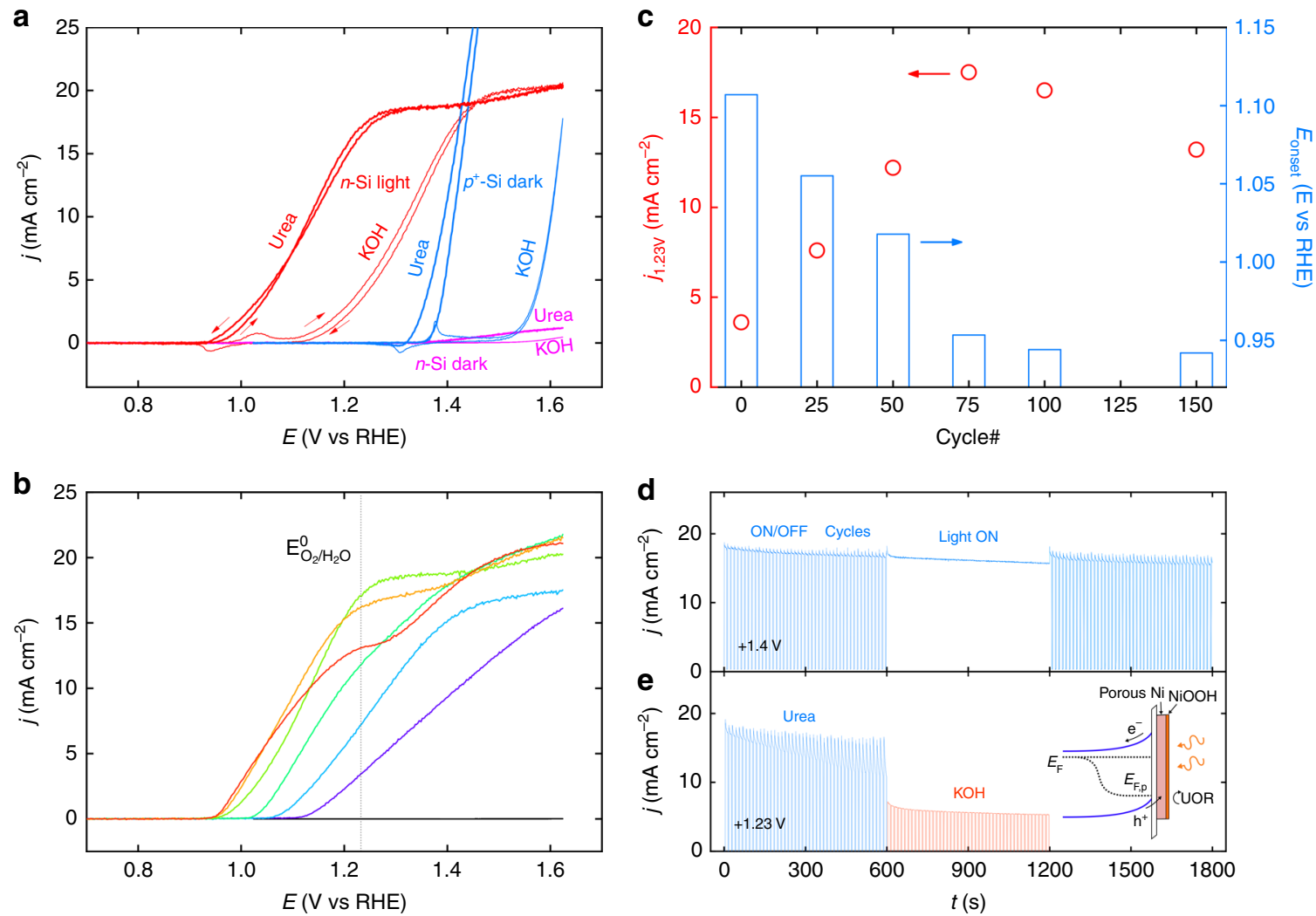

Fig. 6 Photoelectrocatalysis on $n-\mathrm{Si} / \mathrm{SiO}_{x} / \mathrm{Ni} / \mathrm{Ni}(\mathrm{OH})_{2}$. a CVs of (light blue) $p^{+}-\mathrm{Si} / \mathrm{SiO} \times \mathbf{N i} / \mathrm{Ni}(\mathrm{OH})_{2}-75 c y$ in the dark, $(\mathrm{pink}) n-\mathrm{Si} / \mathrm{SiO} \times \mathrm{Ni} / \mathrm{Ni}(\mathrm{OH})_{2}-75 \mathrm{cy}$ in the dark and (red) $n-\mathrm{Si} / \mathrm{SiO}_{x} / \mathrm{Ni} / \mathrm{Ni}(\mathrm{OH})_{2}-75 c y$ under simulated sunlight; the $\mathrm{CVs}$ recorded in $1 \mathrm{M} \mathrm{KOH}$ are represented by thin lines and the $\mathrm{CVs}$ recorded in $0.33 \mathrm{M}$ urea $+1 \mathrm{M} \mathrm{KOH}$ are represented by thick lines. $\mathbf{b} \mathrm{LSV}_{\mathrm{s}}$ of (black) $n-\mathrm{Si} / \mathrm{SiO}_{x}$ and $n-\mathrm{Si} / \mathrm{SiO} \times \mathrm{Ni} / \mathrm{Ni}(\mathrm{OH})_{2}$, prepared with different number of cycles ((purple) 0cy, (light blue) 25cy, (cyan) 50cy, (light green) 75cy, (yellow) 100cy, and (red) 150cy) under simulated sunlight in $0.33 \mathrm{M}$ urea $+1 \mathrm{M}$ $\mathrm{KOH}$. All voltammograms were recorded at $10 \mathrm{mV} \mathrm{s}^{-1}$. c Values of (red disks) $j_{1.23 v}$ and (blue bars) $E_{\text {onset }}$ recorded under simulated sunlight in $0.33 \mathrm{M}$ urea $+1 \mathrm{M} \mathrm{KOH}$. d, e $j$ vs $t$ plots for UOR on $n-\mathrm{Si} / \mathrm{SiO}_{x} / \mathrm{Ni} / \mathrm{Ni}(\mathrm{OH})_{2}-75 c y$ recorded at $1.40 \mathrm{~V}$ (d) and $1.23 \mathrm{~V}$ (e) under intermittent and continuous light illumination in $0.33 \mathrm{M}$ urea $+1 \mathrm{M} \mathrm{KOH}$. In e, the electrolyte was replaced at 600 s by $1 \mathrm{M} \mathrm{KOH}$. Inset: schematic band diagrams of a $n-\mathrm{Si} / \mathrm{SiO} \times \mathrm{Ni} / \mathrm{NiOOH}$ photoanode in operation

the modified ones, which is also observed for the photoactive surfaces (Fig. 6b). In addition, the appearance of a shoulder, observed for the highest cycle numbers $\left(n-\mathrm{Si} / \mathrm{SiO}_{\mathrm{x}} / \mathrm{Ni} / \mathrm{Ni}(\mathrm{OH})_{2}-100 c y\right.$ and $\left.150 c y\right)$ indicates a decrease of UOR activity, which is supported by a larger OER photocurrent density at higher potentials. Because of the photovoltage enhancement (vide supra), the UOR onset potentials ( $E_{\text {onset, }}$, arbitrarily set for $j=100 \mu \mathrm{A} \mathrm{cm}^{-2}$ ) shifted negatively with the cycle number, varying from $1.11 \mathrm{~V}$ vs RHE for the homogeneous MIS $n-\mathrm{Si} / \mathrm{SiO}_{\mathrm{x}} / \mathrm{Ni} / \mathrm{Ni}(\mathrm{OH})_{2}-0 c y$ to $0.94 \mathrm{~V}$ vs $\mathrm{RHE}$ for $n-\mathrm{Si} / \mathrm{SiO}_{\mathrm{x}} /$ $\mathrm{Ni} / \mathrm{Ni}(\mathrm{OH})_{2}-150 c y$ (Fig. $6 \mathrm{c}$ and $\mathrm{S} 26$ ), which is, in any case, lower than what has been reported on conducting catalytic electrodes ${ }^{7-9}$. While at low cycle numbers ( $0 c y$ to $\left.75 c y\right)$, the increase of $V_{\mathrm{oc}}$ and the improvement of the UOR catalysis are cumulative and both contribute to a better overall performance, for high cycle numbers $(>75 c y)$ the catalysis activity decays because both effects become antagonist, decreasing the $j$ value at $E_{\mathrm{O} 2 / \mathrm{H} 2 \mathrm{O}}^{0}\left(j_{1.23 \mathrm{~V}}\right.$, Fig. $\left.6 \mathrm{c}\right)$. In addition, the $\mathrm{CV}$ analysis reveals that high cycle numbers are also detrimental to the photoanode stability (Supplementary Fig. 27). We have thus selected for the following $n-\mathrm{Si} / \mathrm{SiO}_{\mathrm{x}} / \mathrm{Ni} / \mathrm{Ni}(\mathrm{OH})_{2}-75 c y$, which represents the best compromise in terms of activity and stability. From Mott-Schottky (M-S) measurements performed on this electrode, a carrier density of $4 \times 10^{16} \mathrm{~cm}^{-3}$ as well as an effective barrier height $\phi_{\mathrm{b}}=0.84 \mathrm{eV}$ was determined, enabling to build the band diagram of the interface (Supplementary Fig. 28 and details in the Methods section). This value is consistent with previous reports on MIS photoanodes ${ }^{19,20}$ and considerably higher than that measured for the homogeneous $n-\mathrm{Si} / \mathrm{SiO}_{\mathrm{x}} / \mathrm{Ni} / \mathrm{Ni}(\mathrm{OH})_{2}-0 c y$, $\left(\phi_{\mathrm{b}}=0.62 \mathrm{eV}\right)$, which further confirm our hypothesis of a higher band bending caused by the rupture of the $\mathrm{Ni}$ thin film upon electrodissolution (Supplementary Fig. 28b, c). The stability of these photoanodes was tested upon prolonged electrolysis. Figure $6 \mathrm{~d}$ shows a chronoamperometry curve obtained at $1.4 \mathrm{~V}$ vs RHE, in the presence of urea under intermittent light. The current density varied instantaneously upon dark-light cycles and the photocurrent decayed only by $13 \%$ after 30 min (Supplementary Fig. 29a). In Fig. 6e, a similar anode was tested at $1.23 \mathrm{~V}$ vs RHE and after 10 min the electrolyte was replaced by a urea-free solution, which induced a $\sim 3$-fold drop of $j$ with respect to the initial value (Supplementary Fig. 29b), clearly showing the benefit of UOR for improving the photoanode performance at low overpotentials.

\section{Discussion}

In conclusion, we have reported that electrodissolution can be employed on homogeneous $\mathrm{Si} / \mathrm{SiO}_{\mathrm{x}} / \mathrm{Ni} \mathrm{MIS}$ electrodes for improving the intrinsic photoelectrochemical properties of the junction. In addition, we have shown how a redox species can be immobilized on the surface during the dissolution process and how it can be employed to directly probe the 
photoelectrochemical properties of the junction. This method allowed us to unveil the remarkable photovoltage improvement caused by the etching of the initially homogeneous $\mathrm{Ni}$ thin film. A second important effect of the electrodissolution is the increase of the surface density of catalytically active $\mathrm{Ni}$ sites allowing for a considerable improvement of urea oxidation reaction (UOR). Both phenomena were studied independently and then combined to prepare highly active photoanodes for solar-assisted UOR. Our results clearly highlight the benefits of inhomogeneity in MIS photoelectrodes and we believe that this concept could lead to further improvements by further engineering of several parameters such as the $\mathrm{SiO}_{\mathrm{x}}$ layer. In addition, we introduced UOR as a promising Si-compatible anodic reaction for improving the utility as well as the yield of PECs. Although issues related to catalyst deactivation (that could be improved by catalyst optimization $)^{9}$ and compatibility with pure urine still have to be solved to enable real application of such systems, these findings open new doors for the design of artificial leaves, based on abundant materials, which can produce $\mathrm{H}_{2}$ with polluted water under sunlight.

\section{Methods}

Reagents. Acetone (MOS electronic grade, Erbatron from Carlo Erba) and anhydrous ethanol (RSE electronic grade, Erbatron from Carlo Erba) were used without further purification. The ultrapure water had a resistivity of $18.2 \mathrm{M} \Omega \mathrm{cm}$ (Purelab Classic UV). Sulfuric acid (96\%, VLSI grade Selectipur) and hydrogen peroxide (30\%, VLSI, Sigma-Aldrich) were purchased from BASF and Sigma Aldrich, respectively. $\mathrm{KOH}$ (pellets for analysis) was purchased from Merck, $\mathrm{KCl}$ (99\%) was purchased from Acros. Urea, $\mathrm{K}_{3} \mathrm{Fe}(\mathrm{CN})_{6}$ and $\mathrm{K}_{4} \mathrm{Fe}(\mathrm{CN})_{6}$ were purchased from Sigma Aldrich.

Surface preparation. All vials and tweezers used for cleaning of silicon were previously decontaminated in $3 / 1 \mathrm{v} / \mathrm{v}$ concentrated $\mathrm{H}_{2} \mathrm{SO}_{4} / 30 \% \mathrm{H}_{2} \mathrm{O}_{2}$ at $105^{\circ} \mathrm{C}$ for $30 \mathrm{~min}$, followed by copious rinsing with ultrapure water. Caution: the concentrated aqueous $\mathrm{H}_{2} \mathrm{SO}_{4} / \mathrm{H}_{2} \mathrm{O}_{2}$ (piranha) solution is very dangerous, particularly in contact with organic materials, and should be handled extremely carefully. The $n$-type silicon (0.3-0.7 $\Omega \mathrm{cm}$ resistivity, phosphorus-doped, double side polished, $275-325 \mu \mathrm{m})(100)$ and $p^{+}$-type silicon wafers $(0.001 \Omega \mathrm{cm}$ resistivity, borondoped, single side polished $275-325 \mu \mathrm{m})(100)$ were purchased from Siltronix. All the Si surfaces were degreased by sonication in acetone, ethanol, and ultrapure water for $10 \mathrm{~min}$ respectively. The surfaces were then decontaminated and oxidized in piranha solution at $105^{\circ} \mathrm{C}$ for $30 \mathrm{~min}$, followed by rinsing with copious amounts of ultrapure water. FTO-coated glass slides were purchased from Sigma Aldrich. The FTO slides were cleaned by sonication in LGC-300 (Transene), acetone, ethanol, and ultrapure water for $10 \mathrm{~min}$ respectively and dried under Ar flow.

Ni thin film deposition. The 25-nm-thick Ni thin films were deposited on the clean FTO or $\mathrm{Si} / \mathrm{SiO}_{\mathrm{x}}$ surfaces by sputtering with a Leica EM ACE600 coating system (Ni target purity: $99.8 \%$, Leica). The Ar pressure for sputtering was $2 \times 10^{-2}$ mbar and the current $100 \mathrm{~mA}$ (pre-sputtering time of $1 \mathrm{~min}$ ), the thickness of the film was determined in situ by a quartz crystal microbalance. After deposition, the system was degassed with $\mathrm{N}_{2}$.

Electrode fabrication. The coated surfaces were further processed to fabricate electrodes. For FTO/Ni, an electrical contact with a metal wire was created on the top of the conducting slide using silver paste (Radiospares) and copper tape (Radiospares) and the electroactive area was defined using hydrophobic tape (3 M). For $\mathrm{Si} / \mathrm{SiO}_{\mathrm{x}} / \mathrm{Ni}$, the Ohmic contact was done on the backside of $\mathrm{Si}$ wafer by scratching the surface with a diamond glass cutter; then a droplet of InGa eutectic and a metal wire were applied on the scratched part. A thin layer of silver paste was painted to cover the InGa eutectic contact as well as a part of the metal wire. After drying of the paste, epoxy resin (Loctite 9460, Henkel) was deposited to shield the backside and frontside of the surface except an active area comprised between 0.1 and $0.25 \mathrm{~cm}^{2}$, note that the exact geometrical value was precisely measured using the ImageJ software prior to the (photo)electrochemical experiments. The electrodes were baked in the oven at $90^{\circ} \mathrm{C}$ for $1.5 \mathrm{~h}$ to cure the epoxy resin.

Preparation of the NiFePB coatings. The electrodes were electrochemically modified with $\mathrm{NiFePB}$ using a freshly-prepared $5 \mathrm{mM} \mathrm{K}_{3} \mathrm{Fe}(\mathrm{CN})_{6}$ electrolyte $(\mathrm{pH}$ adjusted to 2.5 with concentrated $\mathrm{HCl}$ ). We have tested different electrochemical methods that gave satisfactory results in terms of modification, however, the pulse method was found to give the deposit with the highest catalytic activity for urea oxidation. The electrodes were modified in a two electrode setup using a SP-150 Bio-Logic potentiostat. The Ni-coated electrode was employed as the anode and a large Pt mesh electrode as the cathode in a beaker filled with the electrolyte. The Pt mesh was placed on the beaker wall and the anode was placed in front of the counter electrode and sequential oxidation pulses of $1 \mathrm{~s}$ at $0.67 \mathrm{~mA} \mathrm{~cm}^{-2}$ were imposed followed by resting time of $3 \mathrm{~s}$ at $0 \mathrm{~mA} \mathrm{~cm}^{-2}$. The FTO and the $p^{+}-\mathrm{Si}$ substrates were modified in the dark and the $n$-Si substrates were modified under illumination through the Pt mesh counter electrode with an optical fiber (Fiber Light DC950H from Dolan Jenner) equipped with a 150-W quartz halogen lamp. After the desired number of cycles was imposed, the electrode was removed from the cell, copiously rinsed with water and dried under an Ar stream.

Electrochemical and photoelectrochemical experiments. Cyclic voltammetry (CV), chronoamperometry (CA), and open-circuit potential (OCP) measurements were performed in a three-neck cell comprising a quartz window and gas inlets. The reference electrodes were a $\mathrm{Hg} / \mathrm{HgO}(1 \mathrm{M} \mathrm{KOH})$ electrode for the measurements in alkaline solution and a KCl-saturated calomel electrode (SCE) for the measurements in $1 \mathrm{M} \mathrm{KCl}$. The counter electrode was a graphite rod. The cell was filled with the electrolyte that was degassed with Ar gas before the experiments. The working electrode was placed in front of the quartz window. The light was provided by a solar simulator (LS0106, LOT Quantum Design) equipped with an AM $1.5 \mathrm{G}$ filter. The power density of the light source was measured prior to experiments at the position of the photoelectrode using an ILT1400 radiometer (International Light Technologies) to ensure the right power density $\left(100 \mathrm{~mW} \mathrm{~cm}^{-2}\right)$. Electrochemical measurements were performed with a Zennium potentiostat (Zahner). The potentials versus $\mathrm{Hg} / \mathrm{HgO}(1 \mathrm{M} \mathrm{KOH})$ were converted into potentials versus reversible hydrogen electrode (RHE) using the following relation:

$$
E_{\mathrm{RHE}}=E_{\mathrm{Hg} / \mathrm{HgO}}+0.098+0.059 \mathrm{pH}=E_{\mathrm{Hg} / \mathrm{HgO}}+0.924
$$

All reported potentials were intentionally not corrected by the Ohmic drop. Unless specified, the CVs and LSVs reported in this work were recorded at $10 \mathrm{mV} \mathrm{s}^{-1}$. The first $\mathrm{CV}$ scans were employed to produce Figs. 4 and 6. Impedance and $\mathrm{OCP}$ measurements were performed in Ar-degassed solutions of $1 \mathrm{M} \mathrm{KCl}$ or of $\mathrm{K}_{3} \mathrm{Fe}$ $(\mathrm{CN})_{6} / \mathrm{K}_{4} \mathrm{Fe}(\mathrm{CN})_{6}$ in $0.1 \mathrm{M} \mathrm{KCl}$. The impedance measurements were fitted using an equivalent circuit comprising a resistance (the cell resistance) in series with a resistance and a capacitance in parallel (simulating $\mathrm{SiO}_{\mathrm{x}}$ ) in series with a resistance and a capacitance in parallel (simulating the semiconductor). The Mott-Schottky (M-S) experiments were performed using a graphite counter electrode and a $\mathrm{Pt}$ wire reference electrode in $0.5 \mathrm{mM} / 0.5 \mathrm{mM} \mathrm{K}_{3} \mathrm{Fe}(\mathrm{CN})_{6} / \mathrm{K}_{4} \mathrm{Fe}(\mathrm{CN})_{6}$ in $1 \mathrm{M} \mathrm{KCl}^{37}$. The cell was in the dark and the potential was swept from positive to negative values with a frequency of $10 \mathrm{kHz}$, an amplitude of $10 \mathrm{mV}$ and 300 counts per point. The capacitance values were calculated using the previously-described equivalent circuit. The M-S equation relates the space-charge capacitance $\left(C_{\mathrm{SC}}\right)$ to the applied voltage $(E)$ across a semiconductor-electrolyte junction following:

$$
\frac{1}{C_{\mathrm{sc}}^{2}}=\frac{2}{q N_{D} A^{2} \varepsilon_{0} \varepsilon_{r}}\left(E-E_{\mathrm{fb}}-\frac{k T}{q}\right)
$$

where, $\varepsilon_{r}$ is the relative permittivity of the semiconductor, $\varepsilon_{0}$ is permittivity in vacuum, $A$ is the surface area, $q$ is the unsigned elementary charge, $N_{D}$ is the density of free carriers, $k$ is Boltzmann constant, and $T$ is the temperature. The $\mathrm{x}$ intercept of the linear region of the MS plot is indicative of the flatband potential $E_{\mathrm{fb}}$. In order to check the validity of the curves obtained in Supplementary Fig. 28a we have calculated the doping density based on the following relation, obtained by substitution of the M-S equation:

$$
N_{\mathrm{d}}\left(\mathrm{cm}^{-3}\right)=\frac{1.2 \times 10^{31}\left(\mathrm{~cm} \times F^{-2} \times V^{-1}\right)}{\operatorname{slope}\left(F^{-2} \times \mathrm{cm}^{4} \times V^{-1}\right)}
$$

The slope of $n$-Si/SiO $/ \mathrm{Ni} / \mathrm{Ni}(\mathrm{OH})_{2}-75 c y$ (Supplementary Fig. 28a), gives a $N_{\mathrm{d}}$ value of $4 \times 10^{16} \mathrm{~cm}^{-3}$, which is relatively in good agreement with the resistivity value given by the wafer manufacturer $(0.3-0.7 \Omega \mathrm{cm})$. The barrier height $\left(\phi_{\mathrm{b}}\right)$, was then calculated using the following relation:

$$
\phi_{\mathrm{b}}=-q E_{\mathrm{fb}}+V_{\mathrm{n}}
$$

With $V_{\mathrm{n}}$ being the energy difference between the conduction band and the Fermi level, that was calculated using the following equation:

$$
V_{\mathrm{n}}=k T \ln \left(\frac{N_{\mathrm{c}}}{N_{\mathrm{d}}}\right)
$$

$N_{c}$, the density of states in the conduction band was calculated by:

$$
N_{\mathrm{c}}=2\left(\frac{2 \pi m_{e}^{*} k T}{h^{2}}\right)^{3 / 2}
$$

With $m_{\mathrm{e}}{ }^{*}$ being the effective mass of electron in crystalline $\mathrm{Si}\left(9.389 \times 10^{-31} \mathrm{~kg}\right)$ and $h$ the Planck constant. The above equations allowed to calculate a $V_{\mathrm{n}}$ value of $0.15 \mathrm{eV}$. Thus, using the intersect of the linear fit of the M-S curves shown in Supplementary Fig. 28 values of $0.84 \mathrm{eV}$ and $0.62 \mathrm{eV}$ were calculated for $n-\mathrm{Si} / \mathrm{SiO}_{\mathrm{x}} /$ $\mathrm{Ni} / \mathrm{Ni}(\mathrm{OH})_{2}-75 c y$ and $n-\mathrm{Si}_{2} / \mathrm{SiO}_{\mathrm{x}} / \mathrm{Ni} / \mathrm{Ni}(\mathrm{OH})_{2}-0 c y$, respectively.

Surface characterization. Scanning electron microscopy (SEM) was performed using a JSM $7100 \mathrm{~F}$ (JEOL). The sample was prepared for transmission electron microscopy (TEM) analysis as follows. First, the sample was cut in half using a 
dicing saw fitted with a diamond wire (Precision Diamond Wire Saw, Well 3241, Escil). The two fragments were then glued (G1 epoxy resin with hardener, Gatan) as follows: $\mathrm{Si} / \mathrm{SiO}_{\mathrm{x}} / \mathrm{NiFePB} / \mathrm{glue} / \mathrm{NiFePB} / \mathrm{SiO}_{\mathrm{x}} / \mathrm{Si}$. This mounting was then cut to fit the TEM-slot (Leica) using a dicing saw. It was then glued onto the slot with the epoxy resin. The slot was then fixed onto a tripod using a mounting adhesive (crystal bond 509, cat\#50400-01, Electron Microscopy Sciences) then polished (on both sides) using a sequence of polyamide/diamond papers with a range of particle sizes (from 30 to $1 \mu \mathrm{m}$ ). Finally, a felt polishing pad with colloidal silica was applied, with a final thickness for the area of interest of $20 \mu \mathrm{m}$. The slot was further thinned using dimpling grinder (Model 200, Fischione instruments) down to a 10$\mu \mathrm{m}$-thick target area before being further processed onto an ion milling machine (low angle ion milling and polishing system, Model 1010, Fischione instruments) to reach a final thickness of $<100 \mathrm{~nm}$ for TEM analysis. TEM and scanning transmission electron microscopy (STEM) were performed with a JEM $2100 \mathrm{LaB}_{6}$ (JEOL) equipped with a Silicon Drift Detector (SDD) - X-Max (Oxford Instruments) and the AZtec software to perform energy-dispersive X-ray spectroscopy and elemental mapping. XPS measurements were performed with an $\mathrm{Mg} \mathrm{K}_{\mathrm{alpha}}(\mathrm{h} v$ $=1254.6 \mathrm{eV}) \mathrm{X}$-ray source and an $\mathrm{Al}$ source $(\mathrm{h} v=1486.6 \mathrm{eV})$ using a VSW HA100 photoelectron spectrometer with a hemispherical photoelectron analyzer, working at an energy pass of $20 \mathrm{eV}$ for survey and resolved spectra. The experimental resolution was $1.0 \mathrm{eV}$. Unless specified, $\mathrm{C} 1 \mathrm{~s}$ set at $284.8 \mathrm{eV}$ was used as the energy reference for all the analyses. Transmittance spectra were acquired on a Shimadzu UV-3600Plus photometer with an integrating sphere (ISR-603). Natural air atmosphere was used as $100 \%$ transmittance reference. Fourier transform infrared (FTIR) measurements were recorded in the grazing angle reflectance mode (A 513 accessory from Brüker Optics, $70^{\circ}$ angle, 100 scans, $2 \mathrm{~cm}^{-1}$ resolution) using a Brüker Optics Vertex 70 FT-IR spectrometer equipped with a sensitive liquidnitrogen-cooled MCT photovoltaic detector. The FTIR spectrum of Fig. 1c represents only the $\mathrm{CN}$ stretching region, as several measurements revealed that the other regions of the spectrum were not reproducible (probably due to the very low layer thickness). In order to get a higher signal/noise ratio, the $p^{+}-\mathrm{Si} / \mathrm{SiO}_{\mathrm{x}}$ sample used for this experiment had a Ni layer of $50 \mathrm{~nm}$ and was modified with 150 electrochemical cycles. The cathodic polarization was performed at $+0.2 \mathrm{~V}$ vs SCE for $30 \mathrm{~s}$ in the dark in $1 \mathrm{M} \mathrm{KCl}$, the surface was then rinsed with ultrapure water and dried with Ar. The spectra were manually subtracted from the background (i.e., the spectrum recorded under the same conditions on a $\mathrm{Ni}$-free $\mathrm{Si} / \mathrm{SiO}_{\mathrm{x}}$ surface) and the intensities of the main bands were normalized.

\section{Data availability}

All experimental data within the article and its Supplementary Information are available from the corresponding author upon reasonable request.

Received: 12 June 2019 Accepted: 12 July 2019

Published online: 06 August 2019

\section{References}

1. Lewis, N. S. \& Nocera, D. G. Powering the planet: Chemical challenges in solar energy utilization. Proc. Natl. Acad. Sci. USA 103, 15729-15735 (2006).

2. Nocera, D. G. The artificial leaf. Acc. Chem. Res. 45, 767-776 (2012).

3. Ager, J. W., Shaner, M. R., Walczak, K. A., Sharp, I. D. \& Ardo, S. Experimental demonstrations of spontaneous, solar-driven photoelectrochemical water splitting. Energy Environ. Sci. 8, 2811-2824 (2015).

4. Hunter, B. M., Gray, H. B. \& Müller, A. M. Earth-abundant heterogeneous water oxidation catalysts. Chem. Rev. 116, 14120-14136 (2016)

5. Spöri, C. et al. The stability challenges of oxygen evolving catalysts: towards a common fundamental understanding and mitigation of catalyst degradation. Angew. Chem. Int. Ed. 56, 5994-6021 (2017).

6. Lhermitte, C. R. \& Sivula, K. Alternative oxidation reactions for solar-driven fuel production. ACS Catal. 9, 2007-2017 (2019).

7. Boggs, B. K., King, R. L. \& Botte, G. G. Urea electrolysis: direct hydrogen production from urine. Chem. Commun. 38, 4859-4861 (2009).

8. Forslund, R. P. et al. Nanostructured $\mathrm{LaNiO}_{3}$ Perovskite electrocatalyst for enhanced urea oxidation. ACS Catal. 6, 5044-5051 (2016).

9. $\mathrm{Yu}, \mathrm{Z}$.-Y. et al. Ni-Mo-O nanorod-derived composite catalysts for efficient alkaline water-to-hydrogen conversion via urea electrolysis. Energy Environ. Sci. 11, 1890-1897 (2018).

10. Wang, G. et al. Solar driven hydrogen releasing from urea and human urine. Energy Environ. Sci. 5, 8215-8219 (2012).

11. Rollinson, A. N., Jones, J., Dupont, V. \& Twigg, M. V. Urea as a hydrogen carrier: a perspective on its potential for safe, sustainable and long-term energy supply. Energy Environ. Sci. 4, 1216-1224 (2011).

12. Sun, K. et al. Enabling silicon for solar-fuel production. Chem. Rev. 114, 8662-8719 (2014)

13. Zhang, X. G. Electrochemistry of Silicon and Its Oxide. (Kluwer Academic, New York, 2001)
14. Kenney, M. J. et al. High-performance silicon photoanodes. Science $\mathbf{3 4 2}$ 836-841 (2013)

15. $\mathrm{Hu}$, S. et al. Amorphous $\mathrm{TiO}_{2}$ coatings stabilize $\mathrm{Si}, \mathrm{GaAs}$, and $\mathrm{GaP}$ photoanodes for efficient water oxidation. Science 344, 1005-1009 (2014).

16. Laskowski, F. A. L., Nellist, M. R., Venkatkarthick, R. \& Boettcher, S. W. Junction behavior of $\mathrm{n}$-Si photoanodes protected by thin Ni elucidated from dual working electrode photoelectrochemistry. Energy Environ. Sci. 10, 570-579 (2017).

17. Xu, G. et al. Silicon photoanodes partially covered by $\mathrm{Ni@Ni}(\mathrm{OH})_{2}$ core-shell particles for photoelectrochemical water oxidation. ChemSusChem 10, 2897-2903 (2017)

18. Scheuermann, A. G. et al. Design principles for maximizing photovoltage in metal-oxide-protected water-splitting photoanodes. Nat. Mater. 15, 99-105 (2016).

19. Digdaya, I. A., Adhyaksa, G. W. P., Trześniewski, B. J., Garnett, E. C. \& Smith, W A. Interfacial engineering of metal-insulator-semiconductor junctions for efficient and stable photoelectrochemical water oxidation. Nat. Commun. 8, 15968 (2017).

20. Hill, J. C., Landers, A. T. \& Switzer, J. A. An electrodeposited inhomogeneous metal-insulator-semiconductor junction for efficient photoelectrochemical water oxidation. Nat. Mater. 14, 1150-1155 (2015).

21. Oh, K. et al. Elucidating the performance and unexpected stability of partially coated water-splitting silicon photoanodes. Energy Environ. Sci. 11, 2590-2599 (2018).

22. Loget, G. Water oxidation with inhomogeneous metal-silicon interfaces. Curr. Opin. Colloid Interface Sci. 39, 40-50 (2019).

23. Ellis, D., Eckhoff, M. \& Neff, V. D. Electrochromism in the mixed-valence hexacyanides. 1. Voltammetric and spectral studies of the oxidation and reduction of thin films of Prussian blue. J. Phys. Chem. 85, 1225-1231 (1981)

24. Sinha, S., Humphrey, B. D. \& Bocarsly, A. B. Reaction of nickel electrode surfaces with anionic metal-cyanide complexes: formation of precipitated surfaces. Inorg. Chem. 23, 203-212 (1984).

25. Lambers, E. S., Dykstal, C. N., Seo, J. M., Rowe, J. E. \& Holloway, P. H. Roomtemperature oxidation of $\mathrm{Ni}(110)$ at low and atmospheric oxygen pressures. Oxid. Met. 45, 301-321 (1996).

26. Tricard, S. et al. Sequential growth in solution of NiFe Prussian Blue coordination network nanolayers on Si(100). Surf. Dalt. Trans. 41, 1582-1590 (2012).

27. Bard, A. J. \& Faulkner, L. R. Electrochemical Methods Fundamentals and Applications 2nd edn (John Wiley \& Sons, Inc., New York, 2001).

28. Vogel, Y. B. et al. Reproducible flaws unveil electrostatic aspects of semiconductor electrochemistry. Nat. Commun. 8, 2066 (2017).

29. Loget, G., Fabre, B., Fryars, S., Mériadec, C. \& Ababou-Girard, S. Dispersed Ni nanoparticles stabilize silicon photoanodes for efficient and inexpensive sunlight-assisted water oxidation. ACS Energy Lett. 2, 569-573 (2017).

30. Nakato, Y. \& Tsubomura, H. Silicon photoelectrodes modified with ultrafine metal islands. Electrochim. Acta 37, 897-907 (1992).

31. Hall, D. S., Bock, C. \& MacDougall, B. R. The Electrochemistry of metallic nickel: oxides, hydroxides, hydrides and alkaline hydrogen evolution. J. Electrochem. Soc. 160, F235-F243 (2013).

32. Biesinger, M. C., Lau, L. W. M., Gerson, A. R. \& Smart, R. S. C. The role of the Auger parameter in XPS studies of nickel metal, halides and oxides. Phys. Chem. Chem. Phys. 14, 2434-2442 (2012).

33. Trotochaud, L., Ranney, J. K., Williams, K. N. \& Boettcher, S. W. Solution-cast metal oxide thin film electrocatalysts for oxygen evolution. J. Am. Chem. Soc 134, 17253-17261 (2012).

34. Sun, K. et al. Stable solar-driven water oxidation to $\mathrm{O}_{2}(\mathrm{~g})$ by Ni-oxide-coated silicon photoanodes. J. Phys. Chem. Lett. 6, 592-598 (2015).

35. Yang, J. et al. A multifunctional biphasic water splitting catalyst tailored for integration with high-performance semiconductor photoanodes. Nat. Mater. 16, 335-341 (2017).

36. Yu, X., Yang, P., Chen, S., Zhang, M. \& Shi, G. NiFe alloy protected silicon photoanode for efficient water splitting. Adv. Energy Mater. 7, 1-6 (2017).

37. Xinghao Z. et al., $570 \mathrm{mV}$ photovoltage, stabilized $\mathrm{n}-\mathrm{Si} / \mathrm{CoO}_{\mathrm{x}}$ heterojunction photoanodes fabricated using atomic layer deposition. Energy Environ. Sci. 9 , 892-897 (2016).

\section{Acknowledgements}

This work is funded by ANR (project EASi-NANO, ANR-16-CE09-0001-01). We acknowledge ScanMAT/THEMIS for TEM and Loïc Joanny from ScanMAT/CMEBA for SEM analyses. Thierry Labasque (Geosciences Rennes) and Nina Hüsken are warmly acknowledged for valuable discussions.

\section{Author contributions}

G.L. coined the idea, designed the experiments, analyzed the data, and wrote the manuscript. C.M. and S.A.-G. performed the XPS measurements. V.D. performed and analyzed the TEM data. B.F. performed the FTIR analyzes. A.V. performed the optical measurements. S.F. prepared the samples for TEM analyses. All authors participated in editing the paper. 


\section{Additional information}

Supplementary Information accompanies this paper at https://doi.org/10.1038/s41467019-11432-1.

Competing interests: The authors declare no competing interests.

Reprints and permission information is available online at http://npg.nature.com/ reprintsandpermissions/

Peer review information: Nature Communications would like to thank the anonymous reviewers for their contributions to the peer review of this work.

Publisher's note: Springer Nature remains neutral with regard to jurisdictional claims in published maps and institutional affiliations. (c) (i) Open Access This article is licensed under a Creative Commons Attribution 4.0 International License, which permits use, sharing, adaptation, distribution and reproduction in any medium or format, as long as you give appropriate credit to the original author(s) and the source, provide a link to the Creative Commons license, and indicate if changes were made. The images or other third party material in this article are included in the article's Creative Commons license, unless indicated otherwise in a credit line to the material. If material is not included in the article's Creative Commons license and your intended use is not permitted by statutory regulation or exceeds the permitted use, you will need to obtain permission directly from the copyright holder. To view a copy of this license, visit http://creativecommons.org/ licenses/by/4.0/.

(C) The Author(s) 2019 